Article

\title{
An Empirical Evidence Study of Consumer Perception and Socioeconomic Profiles for Digital Stores in Vietnam
}

\author{
Sonia Singh ${ }^{1}$, Subhra Mondal ${ }^{2, * \mathbb{C}}$, Lata Bajpai Singh ${ }^{3} \mathbb{C}$, Kalyan Kumar Sahoo ${ }^{4}(\mathbb{D}$ and \\ Subhankar Das $2, *$ (D) \\ 1 Higher College of Technology, Toss Global Management, Dubai 400614, UAE; sonia23singh@gmail.com \\ 2 Department of The Honors Program, Duy Tan University, 254 Nguyen Van Linh, Da Nang 550000, Vietnam \\ 3 Department of Rural Management, Babasaheb Bhimrao Ambedkar (Central) University, \\ Lucknow 226025, India; drlatabajpai@gmail.com \\ 4 School of Management and Commerce, KK University, Nepura, Deep Nagar, Bihar Sharif, \\ Bihar 803115, India; dr.kalyan.sahoo@gmail.com \\ * Correspondence: subhra.mondal05@gmail.com (S.M.); info.subhankardas@gmail.com (S.D.)
}

Received: 29 January 2020; Accepted: 21 February 2020; Published: 25 February 2020

check for updates

\begin{abstract}
Digital stores are spreading their tentacles slowly in Vietnam, the most upcoming economy of the ASEAN region, so it is a relevant and contemporary study to know the perceptual thought and socioeconomic profiles of customers. Since there is a lack of independent study in this area, the relationships can be researched and presented. The context of digitization and consumerism is slowly growing in the Vietnamese market. So, this article studies the factors influencing online consumer perception and purchase orientation for digital stores operating in Vietnam through apps and websites. This study is a bi-phase study. In the first phase, constructs, such as digital store images, digital customer loyalty, satisfaction and digital socio-economic profiles of consumers, are examined. In the second part, the empirical analysis is carried by the authors. The study is done by SPSS 22, R studio, and R-cran software packages. Exploratory factor analysis, confirmatory factor analysis, very simple structure (VSS) criterion, and parallel analysis are used for the study. Customers have an almost balanced view of shifting to other stores and the image of the digital store, which makes the price have a substantial effect on the digital store image. The education and empathetic nature of employees also affect the way customers complain, and the way delivery is handled, which is Factor 1 for the model. Factor 2 is promotion, pricing, billing ease, or proper billing, which influence the purchasing power of the customer. So, the service provider or digital store has to be cautious of a specific socioeconomic variable. Digital store image is significantly about complaint handling methods, promotional aspects, and image-driven pricing. So the digital store has to be more careful about these factors. So, from the model, it can be concluded that digital consumers' socioeconomic profiles, the price of the product, and the digital store's image appear to have a significant relationship. A consumer pattern is having the education and the period of purchase, which explains the relationship better. The level of education and the period of purchase from a digital store also have significant differences among each other. Thus, the digital service provider should consider the level of education and the period of continuous purchase from a digital store as the criteria for evaluating digital customer loyalty. The price of the product seems to be significant as a variable too. The digital store image appears to be substantial for grievances, promotion, and image driven by price. So this considerable relationship has to be taken into consideration by the service provider while focusing on making decisions for customer loyalty.
\end{abstract}

Keywords: digital stores; Vietnam; digital customer loyalty and satisfaction; digital store image; digital socioeconomic profile; EFA; CFA; parallel analysis; bi-factor model 


\section{Introduction}

The fastest-growing middle class and the availability of the internet has propelled Vietnam into exponential growth in digital retail outlets. It has opened the Pandora's box of opportunities and challenges for new business ventures and online platforms. The uniqueness of such stores lies in real-time data processing and depends on the experiences they propel for interaction along with payment. The young middle-class consumers, who either have new jobs or are studying, interact by smartphone, tablet, laptop, phablets, or PC. They approach these stores for varying types of reasons. However, young buyers purchase from these stores via apps depending on their positive experiences, confidence, and preferences. However, the digital revolution is in the nascent stage. There is no such available research in Vietnam on consumer preference for digital stores where app-based purchase happens. Although general consumers prefer offline stores mostly, now due to the growth and awareness of applications and online payment gateways, they are slowly venturing to digital stores. Five years ago, the digital revolution started, and now it has picked up speed to be the predominant force to reckon with. For that reason, we have tried to conduct this research to give a substantial model for the sustainable growth of digital stores in Vietnam.

Vietnam's e-commerce industry revolution shows that the digital market is expected to grow to USD 180 billion by 2020 from USD 142 billion in 2018. The total revenue in the e-commerce market in Vietnam amounted to USD $2963 \mathrm{~m}$ in 2019. The annual pertinent pragmatic growth rate is $8.5 \%$, as per the 5-year compounded annual growth rate (CAGR) report 2019-2024, resulting in a market capitalization of USD $4452 \mathrm{~m}$ by 2024. The market's largest segment is fashion merchandise, with a total volume of USD $717 \mathrm{~m}$ in 2019. Online user penetration was $56.7 \%$ in 2019 , and is expected to reach $65.6 \%$ by 2024. The average revenue per user (ARPU) generated currently amounts to USD 54.14 [1]. Due to urbanization, digitalization, and the expansion of the middle class, digital store demand is increasing (Table 1). Vietnam is demographically a vast digitalized country in Southeast Asia. Rapid digital growth is due to functional internet connectivity and dynamic mobile technology. The ongoing digital transformation in the country is expected to increase Vietnam's total internet user base to 59 million by 2019, from 50 million as of December 2018. It will be one of the rapidly growing markets in the world. According to the Digital Market Outlook study of Statista, 50 million Vietnamese e-commerce shoppers have spent a combined USD 2.2 billion, although this figure does not include spending on digital media travel portals and hotel bookings. However, the most promising aspect of all is that Vietnam saw strong growth in online shopping from 2018, with an increase in online purchases by $30 \%$ from 2017 [2]. The online digital Vietnamese shoppers spent nearly USD 6 billion in 2018, which is almost USD 1 billion more than in 2017. Vietnam's e-travel purchases were predominantly placed at $59 \%$ in 2018 for USD 3.5 billion. However, FMCG and FMCD purchases take the dominant share of the Vietnamese e-commerce market at 38\% in 2018 for USD 2.2 billion. They comprise of electronics, apparel, soft toys, and groceries.

Table 1. Digital stores in Vietnam.

\begin{tabular}{ccccc}
\hline Type of Player & Name & Country of Origin & Establishment & Operation Format \\
\hline Domestic & Adayroi & Vietnam & 2015 & B2C \\
Domestic & ChoTot.com & Vietnam & 2012 & C2C \\
Domestic & Shopee.vn & Vietnam & 2016 & C2C \\
Domestic & Sendo.vn & Vietnam & 2012 & C2C \\
Domestic & Tiki.vn & Vietnam & 2010 & B2B2C \\
Foreign & AeonEshop.com & Japan & 2017 & B2C \\
Foreign & Lazada.vn & Germany & 2012 & B2B2C \\
Foreign & Lotte.vn & Korea & 2016 & B2C \\
Foreign & Robins.vn (previously Zalora) & Thailand & 2017 & B2B2C \\
\hline
\end{tabular}

Source: VN-CB-Vietnam-Consumer-Retail-2019. https://www2.deloitte.com/content/dam/Deloitte/vn/Documents/ consumer-business/vn-cb-vietnam-consumer-retail-2019.pdf. 
Within the FMCD sector, electronics purchases have the maximum share of value, although apparel and cosmetics give stiff competition to it. Vietnamese internet users are less interested in digital content, so digital entertainment is particularly weak at USD 21 million in 2018. Large numbers of consumers have transacted digitally over the internet. The development and expansion period for digital markets can last from 15 to 25 years, as the country will be updating its mobile network to 5G. In this period, exponential numbers of digital stores are beginning to develop prominent digital presence and amassing a large consumer base to compete.

Numerous retailers have moved from physical brick-mortar instores to digital stores on the internet, from regional, national, and international levels. In the last one year, Vietnamese consumers have spent USD 558 million on apparel and cosmetic products, USD 610 million on electronic goods, USD 348 million on food and personal care, USD 399 million on furniture and home appliances, USD 354 million on soft toys, USD 3.5 billion on travel and hospitality, USD 21 million on digital entertainment, and USD 75 million on online games. In percentage growth, these items are at $25 \%$, $27 \%, 38 \%, 29 \%, 33 \%, 16 \%, 7.6 \%$, and $23 \%$ growth, respectively, in the last one year [2].

Vietnam's online economy is galloping northwards by $20 \%$ from last year, unsurprisingly. The travel and tourism sector, which is the most dominant of the online market, is growing by below $20 \%$, which is a bit of a concern. However, the consumer market is ahead at $29 \%$ with food and personal care; toys are growing at more than $30 \%$. So, Vietnam is one of the leading online grocery and food markets in the world. The growth rate is $38 \%$, which is very commanding [2]. This trend shows that consumers go for regular repeat purchases of grocery items due to familiarity, ease of operation, and they are now loyal to the process. If these grocery experiences stay positive, then the increased loyalty will bring greater confidence in online shopping. It may help in gathering momentum for increased online shopping across all varieties. Due to the potential significance of the grocery category for Vietnam's e-commerce market, it is evident that consumers are keen to have products across different types.

In Vietnam, Shopee and Lazada dominate the e-commerce landscape. Shopee is the most preferred mobile purchase app, having the highest number of visits with online transactions. It attracted 34 million digital consumer visits per month in 2019 on average. Lazada comes third with 24 million trips [2]. Tiki.vn completes the troika of mobile apps and tours by standing in second place with 27 million, almost 3 million more than Lazada's local site. Some app-only e-commerce platforms such as Adayroi, along with website-only players of e-commerce such as thegioididong.com, chotot.com and dienmayxanh.com are famous for their use in particular devices. Some prefer the app alone so that they use it only on mobile phones, and some prefer websites only on laptops and PCs.

Food with personal care goods accounted for nearly $40 \%$ growth. Grocery spending will double every year between 2017-2022 [2]. In spite of enormous growth, online grocery e-retailing is still lagging. It is projected to hold only less than 0.5 percent of total category spending by 2022 . This low percentage for grocery e-retailing opens the gate to players operating digital stores where they can explore untapped opportunities in the Vietnamese market. Out of the total grocery market of USD 63 billion, online grocery is for around $0.6 \%$ at USD 348 million. A supermarket like Lotte attracts about 1 million footfalls each month, and a food delivery digital store, NOW, which offers grocery items, has an average of 3.5 million visits per month. So clearly, digital stores are picking up. Now Lotte has also come up with an application for this. All these things point to the fact that the trend of online digital stores has picked up the pace, and in the future, it will see a significant boom.

Vietnam has only one-third of its total population in urban areas. A huge population still lives in dispersed rural areas. It makes online penetration a little bit difficult. Card payment and mobile wallets are also at a very precarious position as only 1 in 3 people have a bank account, and 1 in 25 people have a card payment facility [2]. Hence, Vietnam is a cash carry economy. Trends speak about the ever-growing potential of e-commerce in Vietnam. Having started the revolution very late, it is slowly moving. However, the pace is picking up, and hopefully, in the coming days, it will move to greater heights (Table 2). 
Table 2. E-commerce activities for digital stores in Vietnam.

\begin{tabular}{lc}
\hline \multicolumn{1}{c}{ Activity } & \multicolumn{1}{c}{$\begin{array}{c}\text { Percentage of Total Consumers from } \\
(\mathbf{1 6 - 6 4} \text { yrs of Age }\end{array}$} \\
\hline Searching online to buy a product & $89 \%$ \\
\hline Visiting online digital store or site in any device & $79 \%$ \\
\hline Purchasing online a product with any device & $78 \%$ \\
\hline $\begin{array}{l}\text { Purchasing online a product with laptop or desktop } \\
\text { PC through website }\end{array}$ & $40 \%$ \\
\hline Purchasing online a product with mobile phone apps & $58 \%$ \\
\hline \multicolumn{2}{c}{ Source: GlobalWebIndex (Q2 2019) https://datareportal.com/reports/digital-2019-ecommerce-in-vietnam. }
\end{tabular}

Even if there are lots of effort on the academic research front for retail stores, there is still a dearth of empirical analytic models as far as Vietnam's online retail formats or app-based purchases are concerned. The one-line retail industry in Vietnam is competitive and dynamic with an annual growth rate of approximtely 6\% from 2013 to 2018 [3]. Demand for online retail stores (digital stores) is ever-increasing with an expansion of urban consumer demand and new age consumerism and a surge of digital nomads to Vietnam [4,5]. So, the understanding of consumer-related factors for the Vietnam market is essential to place a marketing strategy for all digital stores. So, accumulating all points of view of these considerations, this research tries to provide a framework for Vietnam digital stores. Product assortment has a maximum effect on Vietnamese consumers' purchase orientation, followed by ease and comfort of shopping, price, promotional loyalty campaigns for attracting consumers, and effective service delivery [6]. It also aims to increase traffic for retail stores and increase revenue. Vietnamese consumers are very much environmentally conscious, and with the increase of green consumerism, they are slowly inclined towards less plastic use. So while they seek customized service for their needs, they simultaneously look for more online stores where plastic cutlery use is not encouraged in Vietnam. They prefer chopsticks, which have cultural and environmental values [7].

Vietnam is a predominantly cash-rich economy. However, after 2018, keeping a trend with eco-friendly consumerism and ever-increasing internet facilities, digital money is slowly entering payment structures. Though Vietnamese consumers had initial reservations towards the trustworthiness of digital payment, with the Government's assurance and gradual steps, they have started to use digital payment apps such as VNpay. Here, the assumption of trustworthiness is highlighted for all types of digital payment. It plays an essential sustainable role in digital loyalty and satisfaction of purchase for online stores [8].

The online revolution or digitalization of purchasing is on a very nascent stage in Vietnam, so it will be prudent and pertinent to study the consumers' purchase intentions. The digitalization of food, travel, flight tickets, groceries, and parcel delivery is very much advancing in the Vietnam market due to some social and technical factors such as busy social lifestyles and easy, convenient access to the internet. Several studies have brought out various factors of consumers' evaluation of service quality and service provider attributes [9].

The Vietnamese people are very much family and culture oriented. They exhibit a high degree of ethnocentrism and cultural collectivism, which are key for digital business sustainability. They affect good service quality and amicable behavior of service personnel so much that they help in increasing customer loyalty and satisfaction among Vietnamese consumers [10]. Cultural values mixed with service delivery, customer relations, and informational output always help in generating customer experiences and enriching satisfaction [10].

\section{The Need for the Study}

However, the attributes of digital stores or online shopping (app- or website-based) retail activities have largely been unexplored in Vietnam, especially after 2018. So, in a growing economy like Vietnam, 
this digital revolution in consumers' purchase intentions towards online retail stores is very important to know. The results are targeted to help the pertinent variables or factors of retail purchase in the context of digital stores. It will also substantially add input to the literature on digital store shopping in the emerging economy of other ASEAN countries. So, in this context, the topic is very much necessary to provide a significant output to potential marketers and policymakers. The perception of young consumers who are studying or have just got into the job will be very vital for the growth of e-commerce. Since they are the ones who will dominate the market in the coming days, it is very much prudent to study their perception and what they think about e-commerce. Digital stores in Vietnam are transforming into a competitive platform in which consumers can choose from a wide variety and get the best experience for future intentions.

\section{Theoretical Background}

The theoretical aspect of this study lies in getting the details of the know-how of consumer perception and how it is connected with digital stores. Due to the massive growth of internet connectivity, the digital diaspora has given rise to better consumer interaction with the market place via digital stores either in the form of apps or websites. Consumers are now very influential in affecting purchase behavior digitally by sharing experiences in the way of reviews and ratings. Now, consumers have a more obvious connection with the brand digitally [11]. A multi-item scale was used to find out consumer perceptions and attitudes towards quality and satisfaction [12]. In the context of digital stores, that knowledge can be beneficial but it needs to be known whether instore perceptions and attitudes are driving digital store transactions. Interaction between the consumer and the digital store is unique and, at times, personal. Antecedents of quality and satisfaction are nevertheless essential for consumers but differently understood. Several studies have identified that businesses need to engage consumers digitally as compared to the instore engagement of consumers [13]. Here, researchers further state that the forerunners of consumer engagement are the most critical factors in the context of online brand communities as they depend on experience sharing and real-time involvement. There are three essential dimensions, such as cognition, effect, and action, for individuals in the social network where consumer engagement is concerned. However, the engagement level is still not clearly defined.

It is found out that digital consumers reported undertaking each of the surveyed online activities, except for engaging family or friends to do exercises on their behalf, which were published as being taken by a little under half ( $46 \%$ ) of users. The activities most commonly reported as being undertaken daily were looking for or reading online news $(48 \%)$, streaming content $(39 \%)$, watching or listening to the news $(31 \%)$, or creating and sharing content $(31 \%)$. The data shows that digital consumer behavior is centered around communications, followed by access to information for a variety of purposes [14]. Researchers argue that the way innovative methods are used in creating appeals to relate consumer engagement on various online media, it is very much prudent to study their perceptions and how they react. Since young consumers nowadays are very much tech-savvy and use social media a lot, it is very much essential to know their way of behavior towards digital stores or app-based purchasing [15]. Studies have demonstrated that social media has become a strategic digital platform for online consumers and marketers for influencing products/services, which can instantly create a mass appeal through celebrity endorsement and via word of mouth.

Customer loyalty, which is measured by customer willingness, is the chief architect for the recommendation of various digital store products as it is the main ingredient for customer experience and e-WOM (electronic word of mouth) through social media usage [16]. Authors found out that brand image is the most potent force of loyalty, followed by the quality of products available in digital stores. When the self-image becomes congruent with the digital store image, the customers become loyal ones. Authors point to the aspect of the "hedonic" nature of happiness with the quality of life, which are the end products of digital store image affiliations. They are linked with "nice feelings" affected by "price", "quality", and "reputation" [17]. It is also found that digital store image influences all the components of brand equity by commercial as well as strategic dimensions ( Beristain and Zorrilla 
(2011) [18], although very little is known in this context about digital consumer behavior. Consumers look for a positive experience with ease of operation and qualitative product with price sensitivity for digital stores with apps [18]. Sustainability of digital brand image is very much associated with apps use and how consumers use them along with social media as they propagate the positive experiences through e-WOM [19]. E-WOM determines the online stores' sales, mostly among consumers, as the promotional aspect is now controlled by social media [20]. The loyalty of consumers also depends on how the delivery of products are done to gather positive e-WOM [21].

Perceptual digital store image and prices influence the perception of the digital store brand, which affects the purchase orientation of consumers by perceived risk [22]. At any given time, digital consumers weigh the perceived risk towards a store's products/services in terms of the warranty, exchange, or refunds, or through escrow services guarantees such as PayPal, when both parties are satisfied in a transaction. Consumers use the perceived digital store image to decide to purchase orientation [23]. Also, the retailer can manipulate the factors affecting the vision for influencing the consumers' emotive decisions about purchase activity [24]. Digital customer satisfaction is also essential to the profitability, and it depends on perceived security for mobile payment, interface design, which will help in smooth operation and conscientiousness in the repeated use of payment gateway [25]. Digital customers, especially young ones who are predominantly using mobile phones, can be satisfied if they are given sensitive pricing and value for products for their transactions [26]. Digital customers can also show positive emotional behavior if their grievances are addressed promptly [27]. They can be very much influenced by the human aspect of intangible support associated with product delivery. Courteous behavior and the empathetic nature of employees also generate customer satisfaction for digital stores [28].

\subsection{Research Gap}

The review of existing literature revealed that there is a lack of a solid understanding of what binds consumer perceptions to digital stores. Do digital stores create digital knowledge for consumers? For example, there is no relevant study for Vietnamese digital stores study where the effects can be explained from the perception of consumers operating online or by apps. Also, there is no study on sustainability, suitability, and applicability of digital stores among Vietnamese consumers.

\subsection{Research Motivation}

This study is focused on Vietnam, where there exists an urgent need for promoting sustainable online stores or app-based purchases among young educated consumers. As per the major findings of data of the General Statistics Office of Vietnam in 2015-2016, the average national age is nearly 32. People aged below 24 constitute $39 \%$ of a population of nearly 92 million. Online consumption is set to increase with the growth of the internet and payment facilities. With the government's sustainable digital initiatives coupled with the increasing use of mobile phones, availability of internet data, and more domestic and foreign players coming into the online market, it is very much prudent to study this aspect of digital store acceptability in the Vietnamese market. The researchers found that there are studies on Vietnamese online consumers, but that is restricted to the format and challenges for digital stores to operate and exist in a digitalized form. Most of the available studies are in the general marketing area, focused on the sales perspective and not on the consumer's perspective. So the importance of this research is paramount and will be beneficial to academic and industry viewpoints.

\subsection{Research Problem}

The research problem is to recognize the connection between digital stores, customers, and particular factors from situation along with digital store image, digital customer satisfaction, and loyalty of digital customers for Vietnamese online digital stores among the consumers who have regular exposure to the internet. 


\subsection{Research Question}

So the research question will be themed on what propels the behavioral intentions of consumers of online digital stores. How the digital store image (DSI), digital customer satisfaction (DCS), and digital customer loyalty (DCL) affect purchase behavioral intentions is revealed by studying the digital socioeconomic profiles (DSPs) of Vietnamese consumers for digital stores.

\subsection{Research Objectives}

For this study, authors have taken the following objectives such as

(a) To determine the relationship between digital socioeconomic profiles and digital customer loyalty and satisfaction;

(b) To determine the relationship between digital socioeconomic profiles and digital store image;

(c) To determine the relationship between digital customer loyalty and satisfaction;

(d) To find the subfactors which affect socioeconomic profile, loyalty and satisfaction, and the image of the digital store.

\section{Literature Review and Hypothesis Development}

\subsection{Digital Socioeconomic Profile (DSP)}

Past researchers have investigated consumers' evaluation of a web portal for its service image and how much it can attract traffic based on its popularity [29-32]. Vietnam is a very much an upcoming country, with a rapidly growing middle class and internet tech-savvy consumers who love to use Facebook, Instagram, and Zalo as their preferred mode of social media. They love to sell and buy on Facebook Market and use applications available to them. Potentially they use five types of activities when purchasing. Various kinds of socioeconomic variables have direct existence in Vietnam. They either do a general search for the product or search for information on any device. They do this to collect information. They purchase through any method or PC or mobiles. Some of the high-end consumers use tablets for their convenience. Most young consumers (around $25 \mathrm{yrs}$ of age) are engaged in online purchases. Household income is also in the mid-range for VND 10-30 million. Overall, 39\% of total consumers are purchasing digitally. Consumers are very much technology-oriented, and almost $74 \%$ of the total are well familiar with digital stores [33]. Generally, consumers want to save time, and for convenience of operation, they take to smartphones and websites to order online. They also get a variety of products in one place in real-time. Even if there are issues related to measuring service quality and reducing waiting time, they still go for online stores [34].

\subsection{Digital Customer Satisfaction (DCS)}

The loyalty of digital consumers, value for money, the trust of delivery, and payment reliability affect satisfaction. The digital store image affects the trust proposition along with value perception, and in return, they have a direct impact on loyalty along with satisfaction [35]. Digital consumers' satisfaction will always positively affect the loyalty of digital consumers through technological acceptance and knowledge as it will impact both directly [36]. A digital store's website and application service quality also affect satisfaction and loyalty directly. Digital consumers also feel happy to pay extra for an augmented service, which will enhance their experience positively sometimes. However, the extra cost may not hold the same effect on satisfaction always [37]. Activities associated with digital applications, such as complimentary coupons and promotional activities, give the convenience of shopping, safety, and trust to consumers [38]. Social interactions are also a by-product of satisfaction, which propels the e-WOM. Friends sometimes give purchase arousal with their satisfied e-WOM propositions, which push the consumer to go for it. It is a unique activity where reference groups also play a very vital role in generating consumer satisfaction [39]. Digital consumer satisfaction is also 
loosely based on the desirability of a purchase influenced by peer reviews, the courteous behavior of staff, price sensitivity, purchase convenience and offers, or discounts given by the store [40].

\subsection{Digital Customer Loyalty (DCL)}

Digital consumers' trust, loyalty, and attitude should be properly understood so that effective policy tackling digital retail sales can be framed. A successful digital retailer needs to understand these elements, and that can provide the longevity to stay in the market, which otherwise may be abandoned by the consumers. In this context, customer loyalty is shaped by regular interaction to buy products/services from a particular digital store, and consumer perceptions may be based on digital stores' flexibility to cater to their needs [41]. The loyalty of consumers is also divided into digital brand loyalty, service loyalty, and digital store loyalty. Consumers' devotion towards a brand is affected by how the brand treatment is rendered [42]. These things determine the common approach towards the brand, the attitudinal approach towards the purchasing orientation and the overall approach in the subconscious mind of the consumer. Digital consumer satisfaction can also be seen from assessing the decisions of a digital store to make consumers happy. Here, when consumers are not conscious of promotions, they may be called idly satisfaction. When they do not have any knowledge of new products, even if the loyalty is there, they are called dormant satisfaction. When they are actively satisfied, but they are immune to new promotions, they can be leveled as inertly satisfaction. In these cases, the digital store has to identify when to launch new schemes and how to make consumers aware of all the new consumer-friendly policies [43]. Inspiration to purchase and capacity to expand the store decisions affect the loyalty of consumers. Inspiration is affected by all the inclusions of the store, and the capacity of purchase is influenced by decision consultation with reference groups [44]. Service quality also indirectly affects digital customer loyalty by satisfaction [45]. Digital brand image also affects loyalty [46]. Digital consumers often show loyalty, which is influenced by emotions, satisfaction, and behavioral intentions when they interact online [47].

\subsection{Service Quality}

Quality of service expectation is considered as the notion or beliefs of consumers as a reference for the good performance of the organization and its image [48]. Consumers always compare perceived expectations and actual delivered performance [49]. This is very well defined in the SERVQUAL model [48-52]. Following this, fellow researchers extended this scale of SERVQUAL to retail stores for their impact on image [53], a web service quality model for online stores [54], and along with the performance-based quality model of stores for retail stores that put an emphasis on customer loyalty and satisfaction [55]. However, with no clear consensus on the effect of service quality, especially on the image and trustworthiness of stores that eventually reflects in customer loyalty, the single construct that is calibrated by either one or multiple items indicates consumers' perception for an online store's image represented by a specific provider [56-61]. Hence the subsequent hypothesis is formulated for the digital socioeconomic profiles of consumers and service quality;

$\mathbf{H}_{\mathbf{1}}$ : Digital socioeconomic profile (DSP) has a positive relationship with quality of service.

$\mathbf{H}_{5}$ : Digital customer loyalty and satisfaction (DCLS) has a positive relationship with quality of service.

\subsection{Price of Product}

In the retail market, the price often gives a definite shape to the perceived image of the item in the subconscious minds of consumers [62]. As consumers, in general, show a cost-saving attitude along with a price-comparison policy in their minds, it is essential for stores to address this factor [63]. The price goes up and down and conventionally affect purchase intentions and traffic in a negative reciprocation $[64,65]$. This statement is quite interestingly challenged by the counter-argument that consumers are not averse to paying more for good service quality $[66,67]$. So, effectively, the good image 
of the retailer is basically boiled down to rational relationships defined by service quality and the prices of product assortments offered. Vietnamese consumers generally perceive that high price is an indicator of high quality since they draw satisfaction from the purchase [68]. Conventionally, it is perceived that competitive, low prices attract consumers more for a retail store $[69,70]$. So the following hypotheses are formulated:

$\mathbf{H}_{2}$ : Digital socioeconomic profile (DSP) has a positive relationship with the price of the product.

$\mathbf{H}_{6}$ : Digital customer loyalty and satisfaction (DCLS) has a positive relationship with the price of the product.

\subsection{Promptness of Service}

The service personnel is the center of all types of targeted consumers for enhancing the online shopping experience [71]. Since delivery and customer relationship personnel are the force that directly interacts with the consumer, they are considered to be the most effective touchpoints for stores. These human elements carry the burden of creating a favorable purchase atmosphere for consumers that depict a good image and loyal, satisfied consumers [72]. Support staff for the products always help in creating a good atmosphere for purchases by giving the consumers assurance of quality and customization [73]. Qualitative staff behavior reflects in quick delivery and an effective address of consumer grievances, which ultimately leads to loyalty and satisfaction and that, in the long term, transpires to a good image for Vietnamese consumers [74]. Hence, the following hypothesis has been formulated:

$\mathbf{H}_{3}$ : Digital socioeconomic profile (DSP) has a positive relationship with promptness of service.

$\mathbf{H}_{7}$ : Digital customer loyalty and satisfaction (DCLS) has a positive relationship with promptness of service.

\subsection{Digital Store Image (DSI)}

Digital store image depends on price sensitivity that is affected by easy-to-find low prices, qualitative product availability, along with the convenience of shopping and smooth return policy [75]. The important factor which shapes the digital store's image is its logo and/or apps and/or website interface/address, which represent the theme spirit identification of the organization [76]. These things help in highlighting operational comfort and identification. Previous studies had a different interpretation of the image. However, here, researchers conclude that there are common elements that affect the psyche of the consumer in the identification of the brand. One of the points of building up a specific store picture is to address clients' issues and to make a positive client encounter. The interface of the application or website, timely order fulfillment, communication, promotional coupon, the security of payment leads to a good image of the online portal and generates trust in consumers [77]. Making consumer loyalty may prompt the long haul objective of future benefits and managed business reasonability. Consumer loyalty expands repeat purchase conduct and the buying activity of different items from a similar digital store [78]. Consumers transact with that digital store, which they feel has a connection with them in terms of price sensitivity and a good comfortable environment of operation [79]. They spend money to buy goods and have their satisfaction. So the digital store that gives more satisfaction has a more strong brand image [80]. Consumer patronage of the digital store's image also depends on knowledge of the digital store and an understanding of who frequently visits the digital store [81]. Hence, the following hypotheses are formulated:

$\mathbf{H}_{4}$ : Digital socioeconomic profile (DSP) has a positive relationship with the digital store image.

$\mathbf{H}_{8}$ : Digital customer loyalty and satisfaction (DCLS) has a positive relationship with the digital store image.

The researchers further stressed on satisfaction and trust for the brand in order to have a considerable effect on loyalty and their purchasing orientation. As it were, it is not just administration quality that will drive purchaser fulfillment and reliability. It is not just merchandizing esteem that 
will encourage faithfulness-it is a blend of different variables that influences one another and joins into an entirety that will decide the dedication of a retail customer. Consumers' dependability on the digital store will be lost if his previous interactions are not sufficiently addressed by the online store. The inability to recognize the multidimensional idea of the shopping background has reduced our comprehension of customer encounters. Researchers have felt that previous studies focus mostly on one or two factors. They have never considered all the elements holistically for a study of digital customers' perception and behavior. Knowledge is mainly based on how consumers are treated and how they look at the product and its delivery. So it is always a tricky situation where the factors will still be acting in total.

Promotion in digital consumer behavior for online stores is key for market sustainability in Vietnam. Positive factors of quick product delivery and assurance of quality enhance satisfaction. High price, unavailability of delivery personnel, and bad behavior delay in delivery increase customer dissatisfaction. Customer satisfaction in digital stores or app-based retail formats is significantly related to loyalty and image. Image is what consumers create in their assumption for services, service delivery, perceived quality and value for the product [82]. The online stores should focus on generating customer loyalty by giving qualitative products and enhancing service quality, so for the image of the store, customer satisfaction is intact, to eventually attract more customer loyalty.

Digital store image is positively related to the loyalty of consumers, and satisfaction is directly connected to reliability. When the purchase activity, along with subsequent experiences, is positive, it leads to long term loyalty. So when the consumer who interacts and purchases online becomes satisfied, then only does commitment come into picture after prolonged exposure that presents a favorable image in the minds of consumers. The digital store choice and operation comfort indirectly give satisfaction, but they do not so overwhelmingly affect loyalty. Latent joy also plays an important role where consumers do not know about the brand directly and having no strong commitment but continue to have peace of operation and comfort. So there may be a weak relationship between digital customer loyalty and latent satisfaction. Since digital customer loyalty and satisfaction are considered to be very much synonymous, the researchers have combined them as digital customer loyalty and satisfaction (DCLS). Hence the following hypothesis is formulated:

$\mathbf{H}_{\mathbf{9}}$ : Digital customer loyalty and satisfaction (DCLS) and digital socioeconomic profile (DSP) have interrelationships with each other.

So, taking the above-discussed constructs, the authors try to propose a conceptual framework where there is a relationship between a digital customer profile and digital customer loyalty and satisfaction. The authors have taken the quality of service, price of the product, promptness of service, and the image of the digital store to establish all the relationships. Here, Figure 1 represents the proposed conceptual model for the study. 


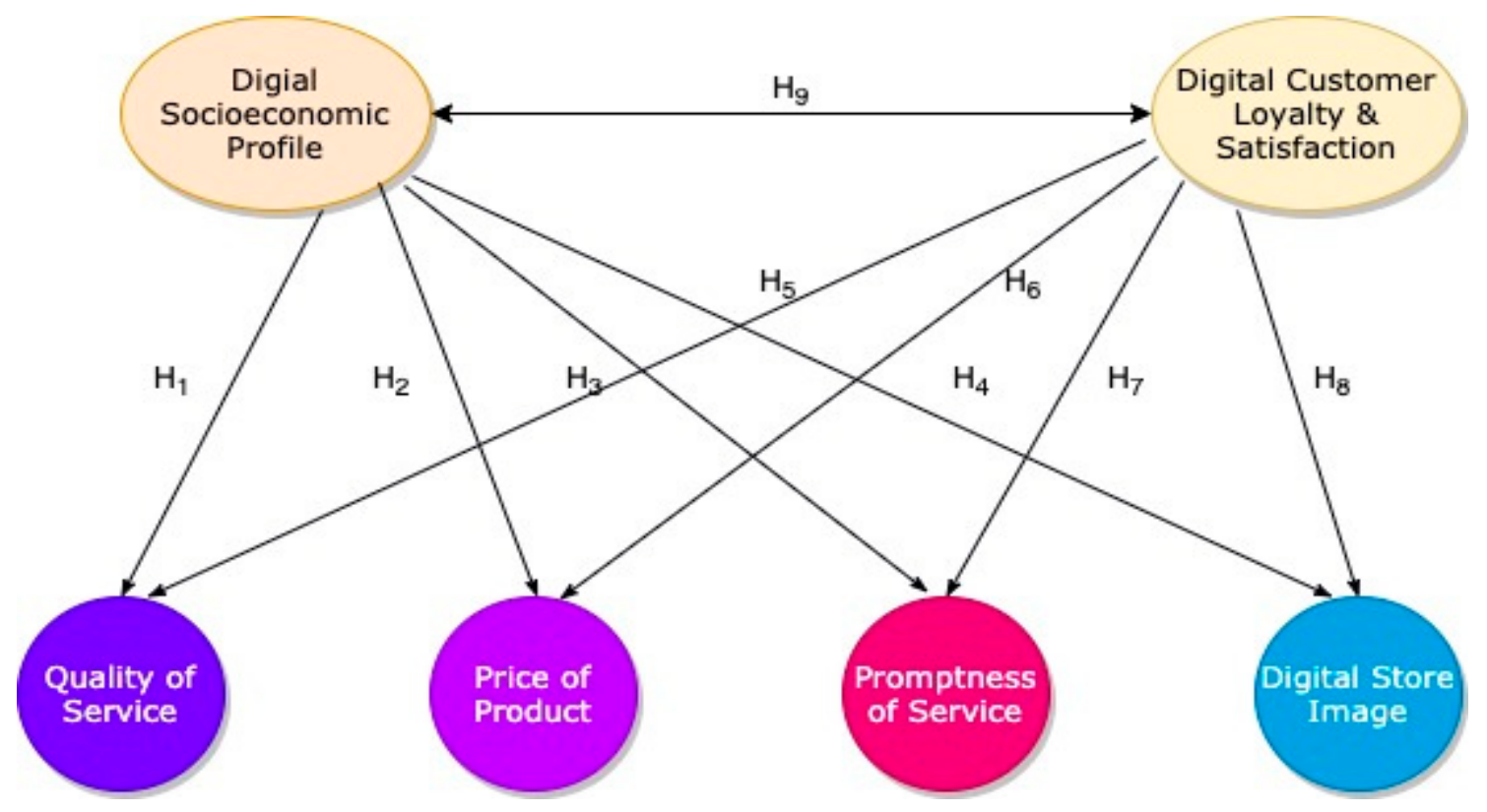

Figure 1. The conceptual model for the study with constructs. Source: authors' conception.

\section{Research Methodology}

This study is a bi-phase study. In the first phase, the primary importance is given to developing an appropriate framework from all the existing applicable literature for constructs such as digital store image, digital customer loyalty, satisfaction and digital socioeconomic profile of consumers. In the second part, the empirical analysis is carried out by the authors. The survey approach is administered for research through a structured questionnaire. Pilot testing has been used for the standardization and validity of constructs.

\subsection{Research Design}

Researchers adopted a deductive and quantitative approach [83]. It helps in investigating the impact of socioeconomic profiles and digital consumers' loyalty satisfaction on service quality, price, promptness of service and online store image. The collection of data is mainly done by circulating the structured questionnaire on Facebook in various public groups available in Vietnam, especially Danang and Hoi An cities. The selection of respondents and segmentation of consumers for digital stores are primarily based on previous studies conducted by researchers for off-line stores and generalized retail activities $[3,5,7]$. The previous researchers segregated the consumers based on the available national census data. So, in this research, the respondents are considered accordingly $[8,9,81,82]$

\subsection{Survey Instrument}

The survey instrument was constructed based on selection and adaptation of existing validated scales in the literature associated with online purchasing orientation. The table below shows how the constructs are presented with their corresponding references. Pretesting of the questionnaire used focus group and cognitive interviews with 16 regular consumers who use online stores for purchasing various products to identify and correct assumed problems pertaining to the structure and layout. The final structure has six segments. The first segment speaks about the socioeconomic profile of digital consumers. The second part signifies the loyalty and satisfaction of the consumer; the third part focuses on service quality. The fourth section sheds light on the price of the product; the fifth one is on the promptness of service, whereas the sixth one is based on the image of the digital store. First, an English version was prepared, then it is translated into Vietnamese by two Vietnamese Master's degree students. After that, the Vietnamese version was translated back to English to counter the original 
English version for rectification. This is done to help appropriate measurement development and to improve consistency and understandability in the use of Vietnamese terminology. All the items are analyzed by 5 -point Likert-type scales where " 1 " represents strongly disagree and " 5 " for strongly agree. The data for the study were collected from respondents who frequently purchase from digital retail stores from August 2019 to November 2019 based on convenience sampling. The initially-expected respondents were 300 , and the structured questionnaire with 21 items was administered. Two hundred seventy-nine respondents gave their responses. However, we finalized 241 valid responses after discarding 38 improperly filled questions and dubious answers, indicating an $80.3 \%$ correct response rate. Table 3 depicts the study constructs for the research compiled by the authors. Table 4 shows the demographic distribution of all respondents.

Table 3. Notation of constructs.

\begin{tabular}{|c|c|c|}
\hline $\begin{array}{c}\text { Study } \\
\text { Constructs }\end{array}$ & Items & References \\
\hline $\begin{array}{c}\text { DSP (cn.p) } \\
\text { Q1-Q5 }\end{array}$ & $\begin{array}{l}\text { Gender. } \\
\text { Educational Qualification. } \\
\text { Age. } \\
\text { Duration of Purchase Experience. } \\
\text { Income. }\end{array}$ & $\begin{array}{l}\text { Mathwick, C., Malhotra, N., \& Rigdon, E., } \\
2001 \text { [29], Yoo, B., \& Donthu, N., } 2001 \text { [30], } \\
\text { Wolfinbarger, M., \& Gilly, M. C., 2003, 3, Jin, B., \& } \\
\text { Park, J. Y., } 2006 \text { [32] }\end{array}$ \\
\hline $\begin{array}{c}\text { DCLS (cn.1) } \\
\text { Q1.1-Q1.5 }\end{array}$ & $\begin{array}{l}\text { Overall satisfied with the online store. } \\
\text { Online store services are close to my expectations. } \\
\text { So I am loyal to the online digital store and consider it to be } \\
\text { the best. } \\
\text { I always recommend the online store among my friends } \\
\text { and relatives. } \\
\text { As a loyalty customer, I am happy with the benefits and } \\
\text { vouchers offered to me. }\end{array}$ & $\begin{array}{l}\text { Manikanandan, } 2012 \text { [37], Chen-Yu, J., \& Hong, K. } \\
\text { H., } 2002 \text { [38], Chang, C. H., \& Tu, C. Y., } 2005 \text { [39], } \\
\text { Grace, D., 2005 [43], Singh, H., \& Prashar, S., } \\
2014 \text { [45], Chebat, J. C., Haj-Salem, N., \& Oliveira, } \\
\text { S., } 2014 \text { [46], Paul, J., Sankaranarayanan, K. G., \& } \\
\text { Mekoth, N., } 2016 \text { [47]. }\end{array}$ \\
\hline $\begin{array}{l}\text { SQ (q1) } \\
\text { Q6-Q10 }\end{array}$ & $\begin{array}{l}\text { The digital store which I prefer offers a wide and extensive } \\
\text { variety of products. } \\
\text { The customer care offers to help me whenever approached for } \\
\text { the order. } \\
\text { The online payment process is safe and quick. } \\
\text { Cash on delivery option is available at the digital retailer. } \\
\text { The store upgrades its services and offers customized service } \\
\text { from time to time depending on customer demand. }\end{array}$ & $\begin{array}{l}\text { Dabholkar, P. A., Thorpe, D. I., \& Rentz, J. O., } \\
1996 \text { [53], Tsikriktsis, N., } 2002 \text { [54], Brady, M. K., } \\
\text { Cronin, J. J., \& Brand, R. R., } 2002 \text { [55], Cronin, J. J., } \\
\text { Brady, M. K., \& Hult, G. T. M., } 2000 \text { [56], Bolton, } \\
\text { R. N., \& Drew, J. H., } 1991 \text { [58], }\end{array}$ \\
\hline $\begin{array}{l}\text { PPD (prc) } \\
\text { Q11-Q13 }\end{array}$ & $\begin{array}{l}\text { The price I pay is at par with the quality of the product } \\
\text { purchased from the retailer. } \\
\text { I am not prepared to pay more for the same type of product } \\
\text { purchased from the retailer. } \\
\text { A higher price of the product will make me switch to a } \\
\text { competitor retailer. }\end{array}$ & $\begin{array}{l}\text { French, S. A., } 2003 \text { [62], Nevin, S., \& Suzan Seren, } \\
\text { K., } 2010 \text { [63], Pan, Y., \& Zinkhan, G. M., } 2006 \text { [65], } \\
\text { Hansen, T., } 2003 \text { [70]. }\end{array}$ \\
\hline $\begin{array}{c}\text { PSC (prm) } \\
\text { Q14-Q17 }\end{array}$ & $\begin{array}{l}\text { I consider prompt and quality customer service as one of the } \\
\text { most important considerations in the evaluatIon of the } \\
\text { online store. } \\
\text { I am not happy with a long delay in delivery I experience } \\
\text { during weekends, holidays and peak hours. } \\
\text { The customer care persons are courteous and friendly in } \\
\text { delivering my order and handling my grievances. } \\
\text { The online store's reputation for good service and quick } \\
\text { delivery is very encouraging for me. }\end{array}$ & $\begin{array}{l}\text { Turley, L. W., \& Chebat, J. C., } 2002 \text { [72], Hu, H., \& } \\
\text { Jasper, C. R., } 2006 \text { [73], Maruyama, M., \& Trung, } \\
\text { L. V., } 2007 \text { [74]. }\end{array}$ \\
\hline $\begin{array}{l}\text { DSI (img) } \\
\text { Q18-Q21 }\end{array}$ & $\begin{array}{l}\text { Digital store's name, variety of products offered, quality of } \\
\text { delivery give a good image in my mind. } \\
\text { The prompt solution to my grievances by customer care } \\
\text { creates a positive image in my mind. } \\
\text { The digital store offers a range of promotions in festivals and } \\
\text { weekends by coupons and loyalty points. } \\
\text { Fair and rational pricing by digital stores promotes its } \\
\text { image positively. }\end{array}$ & $\begin{array}{l}\text { Orel, F. D., \& Kara, A., } 2014 \text { [77], Das, G., } \\
2014 \text { [78], Beristain, J. J., \& Zorrilla, P., } 2011 \text { [80], } \\
\text { Pham, T. H., Nguyen, T. N., Phan, T. T. H., \& } \\
\text { Nguyen, N. T., } 2019 \text { [81] }\end{array}$ \\
\hline
\end{tabular}


Table 4. Socioeconomic profile of respondents.

\begin{tabular}{cccc}
\hline Socio-Economic Variable & Category & Sample & Ratio \\
\hline \multirow{2}{*}{ Gender } & Male & 92 & 38.2 \\
& Female & 149 & 61.8 \\
\hline \multirow{3}{*}{ Education } & High School & 24 & 9.9 \\
& Bachelor & 153 & 63.5 \\
& Master & 53 & 21.9 \\
& Ph.D. & 11 & 4.5 \\
\hline \multirow{3}{*}{ Age } & Below 24 & 80 & 33.2 \\
& $24-34$ & 67 & 27.8 \\
& $35-45$ & 40 & 16.6 \\
Purchase Experience & Over 45 & 54 & 22.4 \\
\hline \multirow{3}{*}{ The income of Family (VND) } & Under-1 yr & 49 & 20.3 \\
& $1-4$ yr & 130 & 53.9 \\
& Over 4 yr & 62 & 25.7 \\
\hline & Under 10,000,000 $0001-20,000,000$ & 93 & 38.5 \\
& Over 30,000,000 & 43 & 17.8 \\
& & 45 & 22.8 \\
& & 73 & 17.8 \\
\hline
\end{tabular}

Source: Data for research.

\section{Data Analysis and Model Testing}

The investigation will expand the knowledge of the findings of customer perception on issues for digital stores that are analyzed fundamentally with regards to the expanding digital marketplace in Vietnam. This study will capture in-depth information about growing digital retail stores in Vietnam. The analysis is done by SPSS 22 and R studio and R-cran software packages [84]. For the simulation of this study, the data sets with a sample size of 241 were used. Since researchers have not designed the factors on sample size, 241 samples will be sufficient for this study [85]. However, with the increase in the complexity of the model, the sample size should be increased [84]. The model consists of two factors and four observed variables. Since the digital stores are in a nascent stage of operation in Vietnam, especially the homegrown ones, we have tried for a simulation study so that we can give an idea of what the consumers want from the apps. Here, the purchase orientation of consumers is mainly simulated as there is no such study available for Vietnam, and our findings may give food for thought for future research for good models and practical benefit. Here, consumer behavior and factors are not compared under EFA and CFA. However, the study targets to show that the data set can fit more than one model in the analysis done by R-Cran. So, in CFA, we have two models to show that data fit more than one model.

\subsection{Exploratory Factor Analysis and Confirmatory Factor Analysis}

For studying the constructs and structure, the authors have employed exploratory factor analysis (EFA), which was done in $\mathrm{R}$ language with the psych package. The underlying assumption for common factor analysis (CFA) is to have a common latent trait. Variables contribute positively to the underlying quality per the CFA. Here the common latent feature is digital customer satisfaction. Secondly, the authors applied a very simple structure (VSS) criterion and parallel analysis to know the structure by default factors.

\subsection{Common Method Factor and Reliability Analysis}

Due to the common method bias causing measurement error, we administered Harman's single factor test in accordance with prescribed guidelines [86-89]. The authors employed exploratory factor 
analysis (EFA) by SPSS-22 for all items measured. The un-rotated factor solutions showed that a single factor shows $37.4 \%$ of the variance in all variables. So, it concludes that common method bias is not likely to affect the sample. Cronbach's alpha values for all constructs ranged from 0.89 to 0.96 . In addition, the corrected item to total correlations is all greater than 0.5 . So, it is assumed that all measures have good internal consistency of reliability [89,90]. Table 5 shows the reliability analysis of the items in questionnaire administered among the respondents \& Figure 2 shows the Graph for $\alpha_{\text {raw }}$ and $\alpha_{d r o p}$ for the sample.

Table 5. Reliability analysis of all items in the questionnaire.

\begin{tabular}{|c|c|c|c|c|c|c|c|c|}
\hline Items & $\mathbf{N}$ & RAW.R & STD.R & R.COR & R.DROP & Mean & Standard Deviation & Cronbach's Alpha \\
\hline 1 & 241 & 0.23 & 0.24 & 0.24 & 0.19 & 4.5 & 0.51 & \multirow{5}{*}{0.89} \\
\hline 2 & 241 & 0.85 & 0.86 & 0.85 & 0.84 & 3.55 & 0.83 & \\
\hline 3 & 241 & 0.12 & 0.09 & 0.08 & 0.05 & 2.57 & 1.12 & \\
\hline 4 & 241 & 0.89 & 0.88 & 0.89 & 0.87 & 1.75 & 0.47 & \\
\hline 5 & 241 & 0.69 & 0.69 & 0.69 & 0.63 & 3.4 & 1.35 & \\
\hline 1.1 & 241 & 0.88 & 0.9 & 0.9 & 0.89 & 3.8 & 0.65 & \multirow{5}{*}{0.92} \\
\hline 2.1 & 241 & 0.91 & 0.93 & 0.91 & 0.92 & 3.92 & 1.13 & \\
\hline 3.1 & 241 & 0.92 & 0.93 & 0.93 & 0.93 & 3.98 & 1.12 & \\
\hline 4.1 & 241 & 0.93 & 0.98 & 0.98 & 0.94 & 3.56 & 0.84 & \\
\hline 5.1 & 241 & 0.98 & 0.99 & 0.98 & 0.95 & 3.58 & 0.83 & \\
\hline 6 & 241 & 0.84 & 0.86 & 0.86 & 0.84 & 3.66 & 0.9 & \multirow{5}{*}{0.96} \\
\hline 7 & 241 & 0.92 & 0.91 & 0.91 & 0.91 & 4.08 & 1.31 & \\
\hline 8 & 241 & 0.79 & 0.72 & 0.91 & 0.78 & 2.64 & 1.08 & \\
\hline 9 & 241 & 0.84 & 0.85 & 0.84 & 0.84 & 4.19 & 1.02 & \\
\hline 10 & 241 & 0.92 & 0.91 & 0.92 & 0.91 & 3.68 & 0.64 & \\
\hline 11 & 241 & 0.92 & 0.95 & 0.94 & 0.9 & 3.57 & 0.93 & \multirow{3}{*}{0.82} \\
\hline 12 & 241 & 0.08 & 0.08 & 0.05 & 0 & 1.49 & 0.53 & \\
\hline 13 & 241 & 0.09 & 0.57 & 0.56 & 0.51 & 1.7 & 0.48 & \\
\hline 14 & 241 & 0.89 & 0.75 & 0.72 & 0.69 & 4.23 & 0.75 & \multirow{4}{*}{0.88} \\
\hline 15 & 241 & 0.55 & 0.56 & 0.55 & 0.53 & 1.67 & 0.49 & \\
\hline 16 & 241 & 0.95 & 0.95 & 0.93 & 0.94 & 4.24 & 1.16 & \\
\hline 17 & 241 & 0.48 & 0.49 & 0.5 & 0.49 & 4.21 & 0.52 & \\
\hline 18 & 241 & 0.01 & 0.02 & 0.05 & -0.01 & 4.38 & 0.56 & \multirow{4}{*}{0.91} \\
\hline 19 & 241 & 0.67 & 0.66 & 0.65 & 0.65 & 4.24 & 0.65 & \\
\hline 20 & 241 & 0.94 & 0.91 & 0.92 & 0.91 & 3.73 & 0.89 & \\
\hline 21 & 241 & 0.59 & 0.59 & 0.58 & 0.56 & 4.54 & 0.56 & \\
\hline
\end{tabular}

Source: SPSS output.

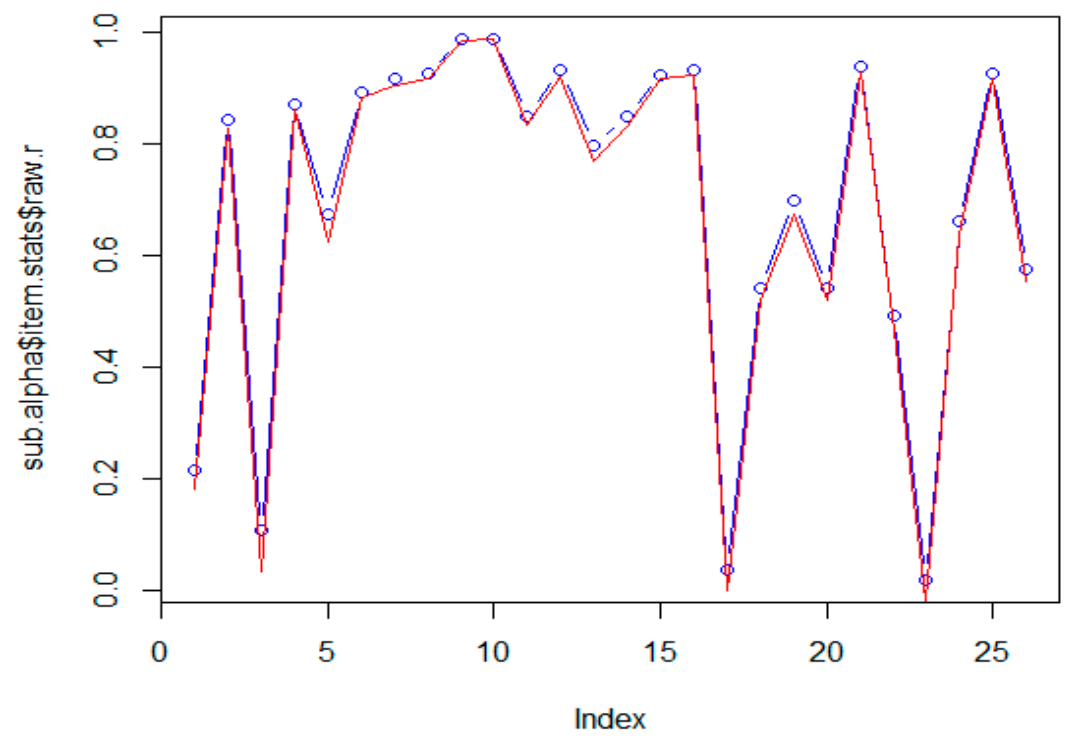

Figure 2. Graph for $\alpha_{\text {raw }}$ and $\alpha_{d r o p}$. Source: SPSS output. 
From the figure, it is observed that $\alpha_{\text {raw }}$ and $\alpha_{d r o p}$ have a sudden drop in the first and last few variables. Alpha is steady for a few common ones. So the first and last few variables show a lot more consistency. Variables of digital socioeconomic profile and digital store image have a particular influence on internal consistency. The alpha value drops a lot when variables such as price, gender, and type of digital store are removed. So they have a lousy impact on internal consistency. So, they are essential in scale measurement for the study. For the optimum number of factors and statistical diagnosis, KMO and Bartlett's test are used and the preliminary analysis is as follows in Table 6.

Table 6. Preliminary study for the optimum amount of factors.

\begin{tabular}{cccc}
\hline No. of Factors & MAP & $\chi^{2}$ & $p$-Value \\
\hline 1 & 0.088139 & $48,940.89$ & 0 \\
\hline 2 & 0.101123 & $48,367.39$ & 0 \\
\hline 3 & 0.114449 & $47,657.23$ & 0 \\
\hline 4 & 0.123432 & $46,861.29$ & 0 \\
\hline 5 & 0.132354 & $45,676.67$ & 0 \\
\hline 6 & 0.162340 & $45,589.89$ & 0 \\
\hline 7 & 0.195129 & $45,346.82$ & 0 \\
\hline 8 & 0.232286 & $43,988.82$ & 0 \\
\hline
\end{tabular}

Here, the researchers used parallel analysis and VSS to determine the optimum number of factors. VSS can be very much used for structures that are not complicated. Here, the chi-square value is extracted until the $p$-value is not significant. So from the table, it is evident that $p$-values are vital for all factors. However, here, the number of factors retention is not precise. So the parallel analysis gives the exact amount of factors to be retained. It is the simulation method where the eigenvalues of correlation matrices will be calculated of uncorrelated standard variables. Based on threshold values specified by researchers, eigenvalues will be selected. In Table 7, the eigenvalues are shown for numerical output in R. Figures 3 and 4 depicts the Number of factors \& non graphical solutions to Scree test for the sample.

\section{Number of factors}

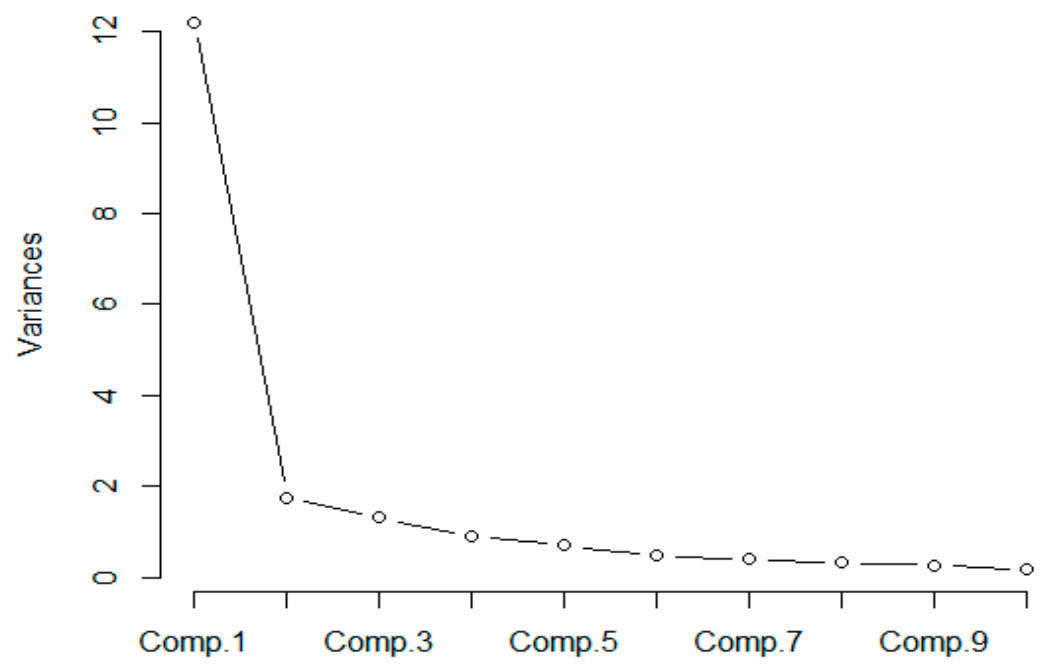

Figure 3. Scree plot for several factors. Source: SPSS output. 
Table 7. Eigenvalues for parallel analysis computed.

\begin{tabular}{|c|c|c|c|c|c|c|c|c|}
\hline & Eigenvalues & Prop & Cumulative & Parallel Analysis & Pred. Eig & OC & Acc. Factor & $\mathbf{A F}$ \\
\hline 1 & 1.73 & 0.06 & 0.06 & 1 & 1.67 & & NA & $(<\mathrm{AF})$ \\
\hline 2 & 1.62 & 0.06 & 0.12 & 1 & 1.59 & & 0.03 & \\
\hline 3 & 1.55 & 0.05 & 0.18 & 1 & 1.51 & & -0.00 & \\
\hline 4 & 1.47 & 0.05 & 0.24 & 1 & 1.44 & & 0.01 & \\
\hline 5 & 1.40 & 0.05 & 0.29 & 1 & 1.37 & & -0.01 & \\
\hline 6 & 1.33 & 0.05 & 0.35 & 1 & 1.31 & & 0.01 & \\
\hline 7 & 1.27 & 0.04 & 0.39 & 1 & 1.26 & & 0.006 & \\
\hline 8 & 1.22 & 0.04 & 0.44 & 1 & 1.21 & & -0.003 & \\
\hline 9 & 1.17 & 0.04 & 0.49 & 1 & 1.16 & & 0.008 & \\
\hline 10 & 1.12 & 0.04 & 0.53 & 1 & 1.12 & $(<\mathrm{OC})$ & -0.008 & \\
\hline 11 & 1.07 & 0.04 & 0.57 & 1 & 1.07 & & 0.01 & \\
\hline 12 & 1.03 & 0.03 & 0.61 & 1 & 1.02 & & -0.009 & \\
\hline 13 & 0.98 & 0.03 & 0.65 & 1 & 0.97 & & 0.004 & \\
\hline 14 & 0.93 & 0.03 & 0.68 & 1 & 0.93 & & 0.001 & \\
\hline 15 & 0.89 & 0.03 & 0.72 & 1 & 0.89 & & -0.003 & \\
\hline 16 & 0.85 & 0.03 & 0.75 & 1 & 0.85 & & 0.005 & \\
\hline 17 & 0.81 & 0.03 & 0.78 & 1 & 0.82 & & 0.005 & \\
\hline 18 & 0.77 & 0.02 & 0.81 & 1 & 0.77 & & -0.01 & \\
\hline 19 & 0.73 & 0.02 & 0.84 & 1 & 0.74 & & 0.01 & \\
\hline 20 & 0.69 & 0.02 & 0.87 & 1 & 0.71 & & -0.002 & \\
\hline 21 & 0.66 & 0.02 & 0.89 & 1 & 0.66 & & -0.004 & \\
\hline 22 & 0.61 & 0.02 & 0.92 & 1 & 0.62 & & 0.0007 & \\
\hline 23 & 0.57 & 0.02 & 0.94 & 1 & 0.58 & & -0.003 & \\
\hline 24 & 0.53 & 0.02 & 0.96 & 1 & 0.54 & & 0.001 & \\
\hline 25 & 0.49 & 0.01 & 0.98 & 1 & NA & & -0.013 & \\
\hline 26 & 0.43 & 0.01 & 1 & 1 & NA & & NA & \\
\hline
\end{tabular}

Non Graphical Solutions to Scree Test

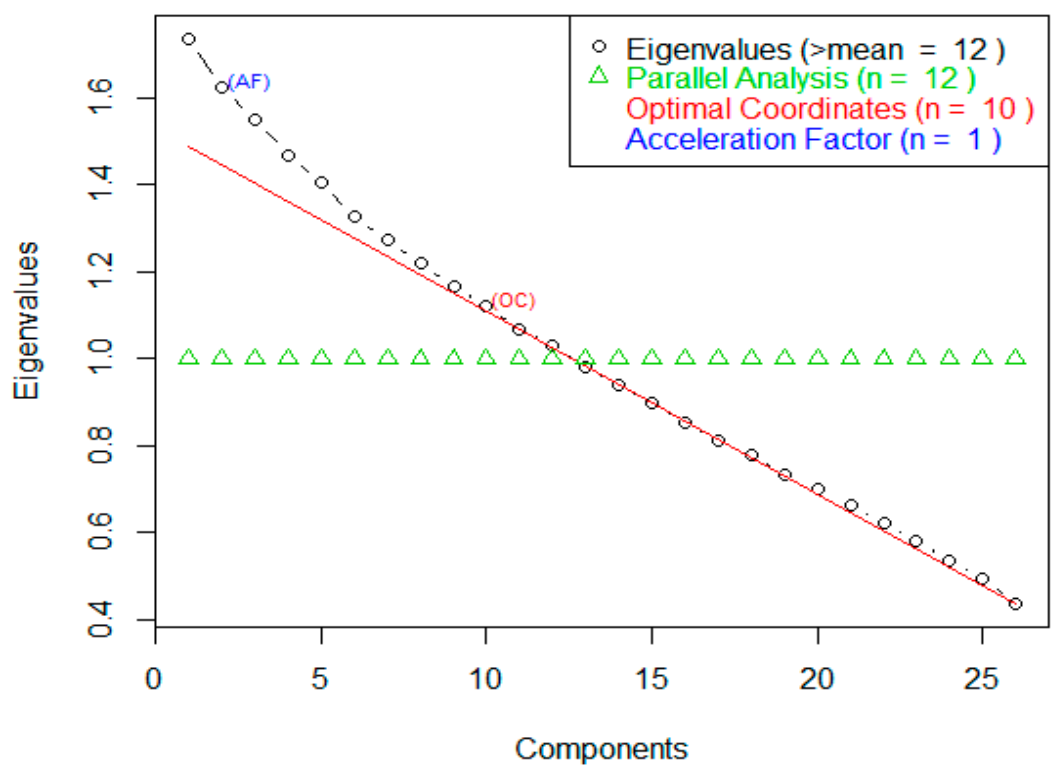

Figure 4. Nongraphical solutions to scree test. Source: SPSS output. 
From Figure 4, it is found that in the first two factors, acceleration is prominent. But Table 7 explains that ten elements are required for a gradient. So, whichever $\mathrm{OC}$ value is more significant than 0.01 will be considered a slope. So, whichever value is less than 0.01 will not explain the variance. AF shows the abrupt change in the curve for those factors, which can tell the difference. Thus this can be subsequently analyzed against common factors for comparison. So Table 8 explains the EFA done in $R$ language, which describes the retention of the bifactor model.

Table 8. EFA summary with R.

\begin{tabular}{cccccccc}
\hline$\chi^{2}$ & $\mathbf{P}$ & $\begin{array}{c}\text { Goodness } \\
\text { of Fit }\end{array}$ & $\begin{array}{c}\text { Root Mean } \\
\text { Square }\end{array}$ & $\begin{array}{c}\text { Cumulative Root } \\
\text { Mean Square }\end{array}$ & $\begin{array}{c}\text { Objective } \\
\text { Function }\end{array}$ & $\mathbf{R}^{2}$ & $\begin{array}{c}\text { Proportion of } \\
\text { Variance }\end{array}$ \\
\hline 438.9653 & $1.94083 \times 10^{-8}$ & 0.89408 & 0.121517 & 0.126784 & 276.2538 & 0.99967 & 0.56 \\
\hline \multicolumn{7}{c}{ Source: Output of exploratory factor analysis (EFA) in R. }
\end{tabular}

The $\chi^{2}$ value is 439 approximately with a $p$-value of $1.94083 \times 10^{-8}$ (approximately 0 ), so it concludes that structure is not a null model. So there exists some structure in the data which can be explained by CFA done in R shown in Table 9.

Table 9. Common factor analysis (CFA) summary with R.

\begin{tabular}{|c|c|c|c|}
\hline Variable & F & $\mathrm{U}^{\wedge} 2$ & Comm. \\
\hline Q1 & -0.202 & 0.959 & 0.04 \\
\hline Q2 & 0.841 & 0.291 & 0.7 \\
\hline Q3 & 0.067 & 0.995 & 0.004 \\
\hline Q4 & 0.861 & 0.258 & 0.741 \\
\hline Q5 & -0.67 & 0.55 & 0.449 \\
\hline Q1.1 & 0.896 & 0.196 & 0.803 \\
\hline Q1.2 & 0.922 & 0.149 & 0.85 \\
\hline Q1.3 & 0.929 & 0.135 & 0.864 \\
\hline Q1.4 & 0.986 & 0.026 & 0.973 \\
\hline Q1.5 & 0.987 & 0.024 & 0.975 \\
\hline Q6 & 0.861 & 0.256 & 0.743 \\
\hline Q7 & 0.943 & 0.11 & 0.889 \\
\hline Q8 & 0.861 & 0.34 & 0.659 \\
\hline Q9 & 0.943 & 0.286 & 0.713 \\
\hline Q10 & 0.811 & 0.13 & 0.869 \\
\hline Q11 & 0.844 & 0.117 & 0.882 \\
\hline Q12 & 0.932 & 0.999 & $2.16 \times 10^{-5}$ \\
\hline Q13 & 0.939 & 0.712 & 0.287 \\
\hline Q14 & -0.004 & 0.53 & 0.469 \\
\hline Q15 & -0.536 & 0.714 & 0.285 \\
\hline Q16 & 0.928 & 0.137 & 0.862 \\
\hline Q17 & 0.527 & 0.721 & 0.278 \\
\hline Q18 & 0.03 & 0.998 & 0.001 \\
\hline Q19 & 0.651 & 0.575 & 0.424 \\
\hline Q20 & 0.925 & 0.143 & 0.856 \\
\hline Q21 & 0.608 & 0.63 & 0.369 \\
\hline
\end{tabular}


So, by VSS and parallel analysis, it was found that there are two factors in data. The gender of digital socioeconomic profile $(-0.20)$, occupation $(-0.67)$, is significantly related to quality $(-0.004,-0.534)$ and price of the product (-0.5367). Other variables have got positive loadings in CFA. Here, education of the digital socioeconomic profile has a decisive factor loading with factors related to digital customer loyalty and satisfaction, customer care and digital store image. So the structure comes out as:

$$
\begin{gathered}
\text { Factor }=0.84(\text { Education })-0.20(\text { Gender })-0.67(\text { Occupation })+0.94(\text { Loyalty \& Satisfaction }) \\
+0.40(\text { Customer Care })+0.55(\text { Image })+0.87(\text { Quality })+0.13(\text { Price })
\end{gathered}
$$

Also, some variables in the quality \& price of products are observed to be a significant relationship with their respective factors.

$$
\begin{gathered}
\text { Quality }=0.65(\text { Quality creates favourability })-0.004 \text { (Quality of Product }) \\
-0.53(\text { Quality of Customer care })
\end{gathered}
$$

Here, the data for quality of the product affects the digital store image and generates support for the store; customers may not go for too much variety. Customer care may not always be crucial for digital customers, where they seek quick action for their real-time interactions. This summarises that digital customers look for qualitative service at one go, corresponding to the delivery of the product. So the price is represented by

$$
\begin{gathered}
\text { Price }=0.93 \text { (Price) }+0.68 \text { (Higher price makes customers' switch }) \\
+0.54 \text { (Price affects image })-0.53 \text { (Don't prefer to pay for same product })
\end{gathered}
$$

So, the price of products affects digital store image, switching of customers along with the variety available to them. For customers, switching to other stores \& the model for it are found to be at the same level for price sensitivity. That reflects that price makes the customer change to other stores. Digital customers are price sensitive. Product variety is also essential to the pricing aspect. So the CFA structure is represented as follows in Figure 5:

\section{Factor Analysis}

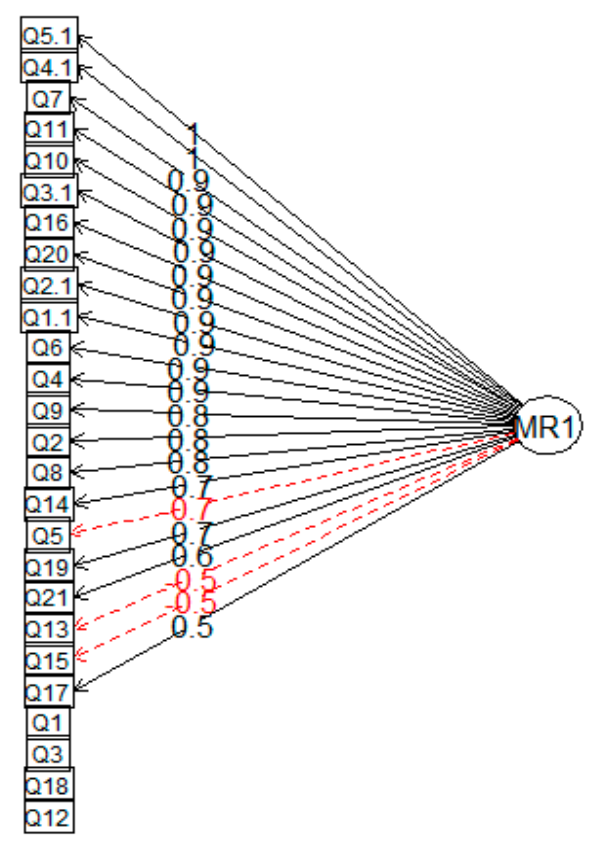

Figure 5. CFA structure diagram for factor analysis. Source: CFA output. 


\subsection{Bi-factor Analysis}

Since researchers have proposed a bi-factor analysis, as shown in the research methodology section, so here, the statistics of the bi-factor structure will be discussed from Table 10 and analyzed for the existence of such a structure.

Table 10. Bi-factor sstructure sstatistics.

\begin{tabular}{cccccccccc}
\hline$\chi^{2}$ & $p$ & $\begin{array}{c}\text { Goodness } \\
\text { of Fit }\end{array}$ & $\begin{array}{c}\text { Root Mean } \\
\text { Square }\end{array}$ & $\begin{array}{c}\text { Cumulative Root } \\
\text { Mean Square }\end{array}$ & $\begin{array}{c}\text { Objective } \\
\text { Function }\end{array}$ & $\mathbf{R}^{2}$ & \multicolumn{2}{c}{$\begin{array}{c}\text { Proportion of } \\
\text { Variance }\end{array}$} \\
\hline 319.87 & 0.029 & 0.949 & 0.106 & 0.115 & 274.04 & 0.99967 & 0.9978 & 0.578 & 0.092 \\
\hline \multicolumn{8}{c}{ Source: Bi-factor output in R. }
\end{tabular}

A $p$-value of 0.029 is not so significant, as compared to CFA. Though there is some degree of support for the proposed bi-factor structure, it is not so keen to be considered. The goodness of fit is nearly one, and the $\mathrm{R}^{2}$ is also close to 1 , with proportionate variance relatively good at 0.578 . So robust support is absent in the bi-factor structure and not so strong in the analysis. The factor loadings are discussed below from Table 11:

Table 11. Bi-factor structure factor loadings.

\begin{tabular}{|c|c|c|c|c|}
\hline Variables & F1 & F2 & $\mathrm{U}^{\wedge} 2$ & Comm. \\
\hline 1 & -0.209 & -0.189 & 0.912 & 0.089 \\
\hline 2 & 0.847 & 0.057 & 0.263 & 0.738 \\
\hline 3 & 0.066 & -0.053 & 0.993 & 0.006 \\
\hline 4 & 0.862 & -0.058 & 0.256 & 0.745 \\
\hline 5 & -0.660 & 0.408 & 0.447 & 0.554 \\
\hline 1.1 & 0.896 & -0.081 & 0.196 & 0.804 \\
\hline 2.1 & 0.926 & 0.037 & 0.125 & 0.877 \\
\hline 3.1 & 0.931 & -0.067 & 0.134 & 0.868 \\
\hline 4.1 & 0.984 & -0.177 & 0.025 & 0.976 \\
\hline 5.1 & 0.985 & -0.289 & 0.012 & 0.981 \\
\hline 6 & 0.866 & 0.056 & 0.228 & 0.773 \\
\hline 7 & 0.946 & -0.004 & 0.095 & 0.904 \\
\hline 8 & 0.810 & -0.134 & 0.349 & 0.659 \\
\hline 9 & 0.846 & -0.062 & 0.284 & 0.717 \\
\hline 10 & 0.935 & -0.019 & 0.112 & 0.880 \\
\hline 11 & 0.941 & -0.079 & 0.115 & 0.885 \\
\hline 12 & 0.023 & 0.906 & 0.165 & 0.836 \\
\hline 13 & -0.516 & 0.726 & 0.275 & 0.726 \\
\hline 14 & 0.675 & -0.389 & 0.438 & 0.561 \\
\hline 15 & -0.526 & 0.310 & 0.656 & 0.342 \\
\hline 16 & 0.923 & -0.280 & 0.112 & 0.889 \\
\hline 17 & 0.539 & 0.325 & 0.564 & 0.437 \\
\hline 18 & 0.042 & 0.281 & 0.916 & 0.085 \\
\hline 19 & 0.651 & -0.089 & 0.576 & 0.425 \\
\hline 20 & 0.919 & -0.289 & 0.116 & 0.885 \\
\hline 21 & 0.619 & 0.293 & 0.489 & 0.512 \\
\hline
\end{tabular}


Here, the bi-factor model is not a lot different from the common factor. However, occupation is opposed to gender. The importance is here in explaining the second factor in terms of the variety of the product offered, product quality and empathetic employees. The reputation of the digital store has some relationship with education, unlike that of the standard factor model. So, here we can get more inference from the second factor, unlike that of the first factor. So the structure diagram of the second factor is represented in Figure 6.

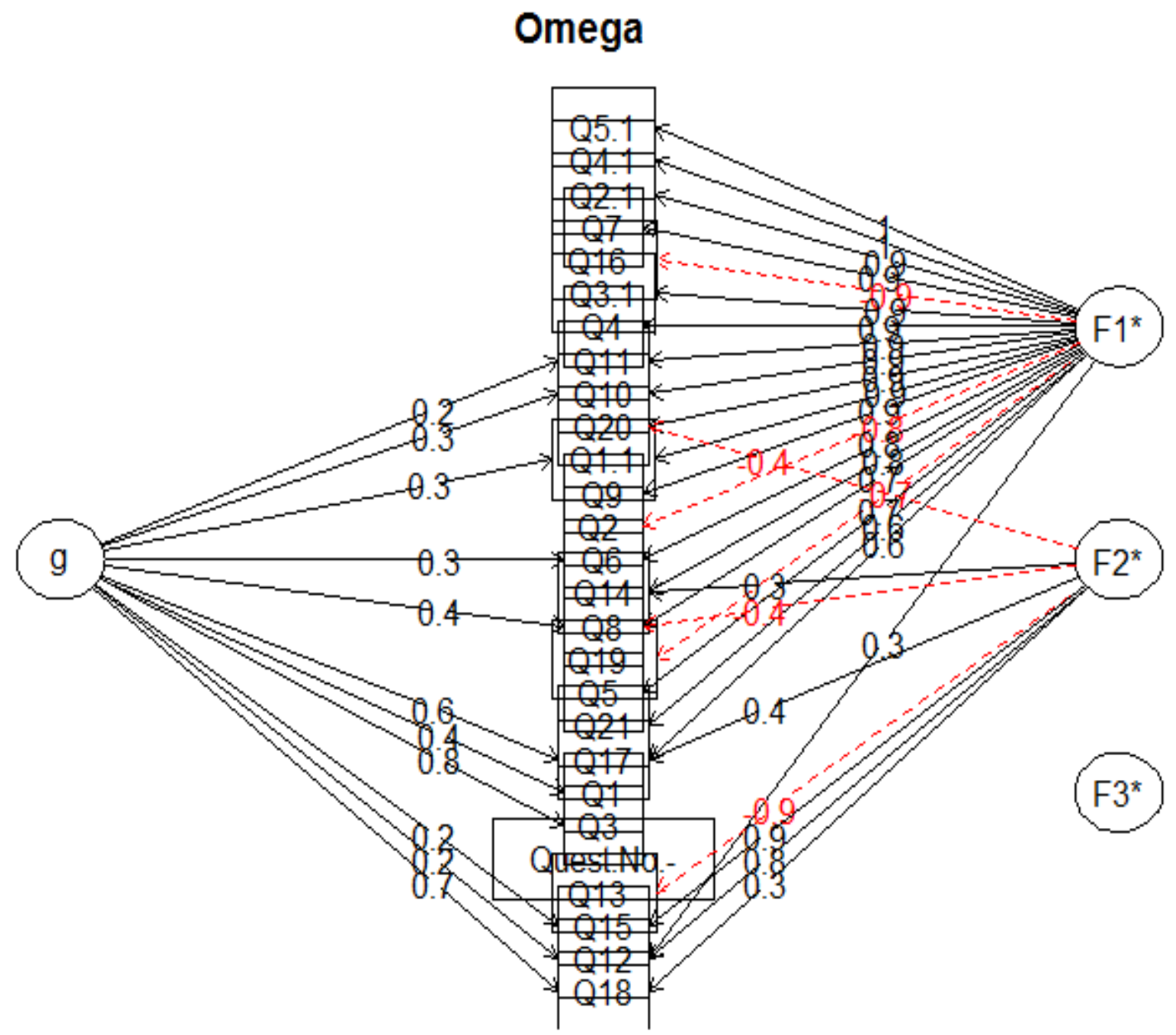

Figure 6. Omega structure of the second factor. Source: Output from R.

\subsection{Confirmatory Factor Analysis by $R$}

As it is already known that the data show certain valid factors (structure). However, the structure provided by EFA is only as a matter of heuristics or unsupervised. As it was evident from the analysis that there two determinative factors, this means that there is a hidden two-factor structure in the data. The study proposes certain logical constructs such as a digital socioeconomic profile of the customer, digital customer loyalty and satisfaction, quality of service given, price of the product, promptness of service to customers, and the digital store image. So the study attempts to propose the following structure.

So, Structure 1 is

$$
\begin{aligned}
& \text { Digital Socioeconomic Profile + Digital Consumer Loyalty } \\
& =\sim \text { Quality + Price + Promptness + Image }
\end{aligned}
$$


Similarly Structure 2 is

Digital Consumer Loyalty Digital Socioeconomic Profile

The notations $=\sim$ and $\sim \sim$ are notations used to perform CFA in R. The LHS of the first expression are latent variables, and RHS are manifest variables. The following expression deals with the covariance of the structure. These expressions stand as the proposed structure for testing. The study proposed two models, one with a straightforward structure, which means the model with only first expression in structure 1 . The second model is with both expressions structure $1 \& 2$. The following is the output for Structure 1.

$\mathrm{R}$ statistics with (> sum.sub.fit <-summary (fit) lavaan(0.5-18) normally converged after 1672 iterations with Estimator ML, we got a user model and a baseline model, then both the models were compared to find the comparative fit index (CFI) and the Tucker-Lewis index (TLI) as shown in Table 12.

Table 12. Model comparison with R statistics for Model 1.

\begin{tabular}{lclc}
\hline \multicolumn{2}{c}{ Model Test for User Model } & \multicolumn{2}{c}{ Model Test for Baseline Model } \\
\hline Minimum Function Test Statistic & $20,935.616$ & Minimum Function Test Statistic & $27,706.056$ \\
\hline Degree of Freedom & 284 & Degree of Freedom & 325 \\
\hline$p$-value (Chi-square) & 0.000 & $p$-value (Chi-square) & 0.000 \\
\hline & Source: Output by R statistics.
\end{tabular}

It is found that there is sufficient support for the proposed structure: A $p$-value of 0 with the $\chi^{2}$ value of 20935.616. A $\chi^{2}$ value of such size is almost impossible. The following output shows the proper measures for the evaluation of the model. By comparing both, we calculated the CFI and TLI values along with root mean square error of approximation (RMSEA), and standardized root mean square residual (SRMR) and it is presented in Table 13.

Table 13. R statistics for both model comparison for Model 1.

\begin{tabular}{|c|c|}
\hline \multicolumn{2}{|c|}{ User Model vs. Baseline Model } \\
\hline Comparative fit index (CFI) & 0.247 \\
\hline Tucker-Lewis index (TLI)S & 0.138 \\
\hline \multicolumn{2}{|c|}{ Loglikelihood and Information Criteria } \\
\hline Loglikelihood user model $\left(\mathrm{H}_{0}\right)$ & -2208.5 \\
\hline Loglikelihood unrestricted model $\left(\mathrm{H}_{1}\right)$ & 8259.308 \\
\hline \multicolumn{2}{|c|}{ No. of free parameters (67) } \\
\hline Akaike (AIC) & 4552.000 \\
\hline Bayesian (BIC) & 4767.843 \\
\hline Sample size adjusted Bayesian (SABIC) & 4555.623 \\
\hline \multicolumn{2}{|c|}{ Root Mean Square Error of Approximation (RMSEA) } \\
\hline RMSEA & 0.623 \\
\hline $90 \%$ confidence level & $\begin{array}{l}0.616 \\
0.63\end{array}$ \\
\hline$p$-value RMSEA $(<=0.05)$ & 0.000 \\
\hline \multicolumn{2}{|c|}{ Standardized Root Mean Square Residual } \\
\hline SRMR & 0.276 \\
\hline
\end{tabular}


It is observed that CFI is 0.247 , and TLI is 0.138 . CFI is always greater than TLI, but the values are poor. The typical values required for assessing fit should be at least 0.9 . It shows that the proposed structure does not appear to be fit. RMSEA is 0.623 ; the null hypothesis that the residuals are zero is rejected. The error appears to be influential in the model. We may not be able to accept the null hypothesis that the error in the population is zero. However, this might be due to sampling error. These observations are very much supported by SRMR (0.276). The last measure is, of course, the Hoelter index, which needs to be computed manually. The following is the Hoelter index value computed in $\mathrm{R}$ by (>Hoelter.index $(20935.615,284,241)$ [1] 4.151499). The value is less than 75 , so there is not enough evidence in support of the study hypothesis. The following is the visualization of the CFA. The following Figure 7 is the visualization for study proposition one.

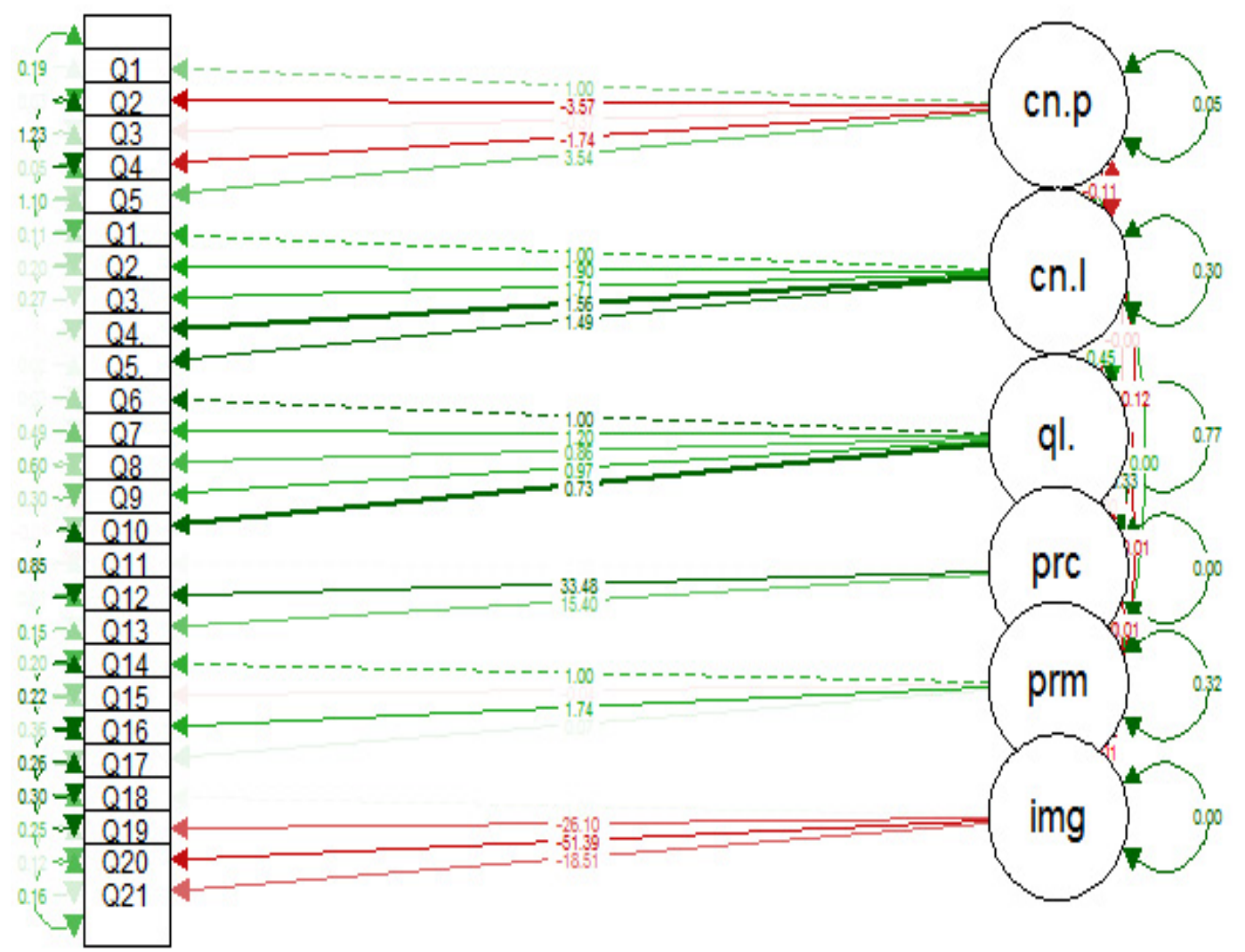

Figure 7. Visualization of study propositions Model 1. Source: Output from R statistics.

So, there are few relationships between digital socioeconomic profile and the digital store image which are significant. Mostly, the store or website image of the service provider is substantial with complaint handling, promotional offers, and pricing of the product. So, service providers need to be cautious with these variables when they think of the image of the digital store.

The Tables 14 and 15 represented output for the second model by command $>$ sum.sub.fit2<-summary(sub.fit2,fit.measure $=$ TRUE) lavaan (0.5-18) converged normally after 4746 iterations with Estimator ML.

Table 14. Model comparison with R statistics for Model 2.

\begin{tabular}{lclc}
\hline \multicolumn{2}{c}{ Model Test for User Model } & \multicolumn{2}{c}{ Model Test for Baseline Model } \\
\hline Minimum Function Test Statistic & $21,216.385$ & Minimum Function Test Statistic & $27,706.056$ \\
Degree of Freedom & 290 & Degree of Freedom & 325 \\
$p$-value (Chi-square) & 0.001 & $p$-value (Chi-square) & 0.001 \\
\hline
\end{tabular}


Table 15. R statistics for both model comparison for Model 2.

\begin{tabular}{|c|c|}
\hline \multicolumn{2}{|c|}{ User Model vs. Baseline Model } \\
\hline Comparative fit index (CFI) & 0.237 \\
\hline Tucker-Lewis index (TLI)S & 0.144 \\
\hline \multicolumn{2}{|c|}{ Loglikelihood and Information Criteria } \\
\hline Loglikelihood user model $\left(\mathrm{H}_{0}\right)$ & -2348.886 \\
\hline Loglikelihood unrestricted model $\left(\mathrm{H}_{1}\right)$ & 8259.308 \\
\hline \multicolumn{2}{|c|}{ No. of free parameters $(61)$} \\
\hline Akaike (AIC) & 4819.770 \\
\hline Bayesian (BIC) & 5017.193 \\
\hline Sample size adjusted Bayesian (SABIC) & 4823.978 \\
\hline \multicolumn{2}{|c|}{ Root Mean Square Error of Approximation (RMSEA) } \\
\hline RMSEA & 0.620 \\
\hline $90 \%$ confidence level & $\begin{array}{l}0.613 \\
0.628\end{array}$ \\
\hline$p$-value RMSEA $(<=0.05)$ & 0.05 \\
\hline \multicolumn{2}{|c|}{ Standardized Root Mean Square Residual } \\
\hline SRMR & 0.295 \\
\hline
\end{tabular}

The structure is evaluated based on fit indices. The following is the out for CFA performed in R. The fit indices appear to be more or less the same as that of the first model except for the $\chi^{2}$ value, which is 21216.384. So obviously AIC, BIC, and SABIC are also different as they depend on the $\chi^{2}$ value. However, this is only an intuitive observation. The following output for model comparison shows whether the difference is significant or not in Table 16.

Table 16. Chi-square difference test.

\begin{tabular}{cccccccc}
\hline Fit for Model & $\begin{array}{l}\text { Degree of } \\
\text { Freedom }\end{array}$ & AIC & BIC & Chi-Square & $\begin{array}{c}\text { Chi-Square } \\
\text { Difference }\end{array}$ & $\begin{array}{c}\text { Degree of Freedom } \\
\text { Difference }\end{array}$ & Pr(>Chi-Square) \\
\hline Fit for Model 1 & 284 & 4552.0 & 4767 & 209,935 & & \\
\hline Fit for Model 2 & 290 & 4819.7 & 5017.2 & 21,216 & 281 & 6 & $<2.2 \times 10^{-16}$ \\
\hline \multicolumn{7}{c}{ Source: Output from R statistics significance codes. }
\end{tabular}

So, the chi-square difference test is also done with the command >anova(fit, sub.fit 2 )

Though the models appear to be more or less the same, the difference seems to be significant. The $\chi^{2}$ difference of 281 is significant, with a $p$-value of 2.2e-16. The following Figure 8 is the visualization of the study Model 2. 


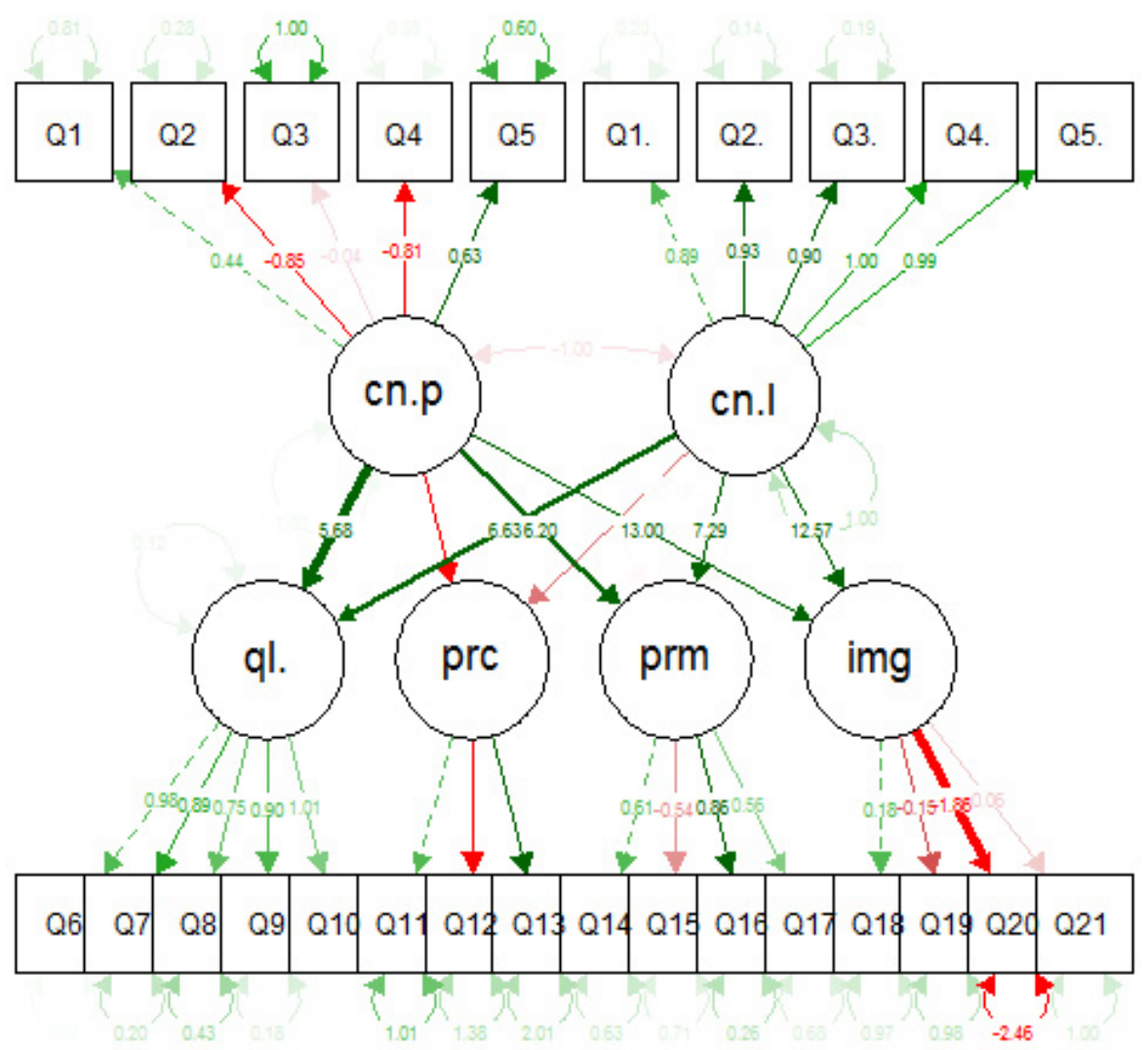

Figure 8. Visualization of study propositions Model 2 (red marked lines showing not so significant relation). Source: Output from R statistics.

\section{Important Findings and Discussions from the simulation}

The consolidated final decision outcome for the simulated hypothesis study is represented in Table 17.

Table 17. Simulation decision table.

\begin{tabular}{clc}
\hline Hypothesis & Beta & Decision \\
\hline H1 & 5.687 & Supported \\
H2 & -1.011 & Balanced \\
H3 & 6.623 & Supported \\
H4 & 13.001 & Supported \\
H5 & 6.632 & Supported \\
H6 & -0.031 & Balanced \\
H7 & 7.297 & Supported \\
H8 & 12.574 & Supported \\
H9 & -1.001 & Balanced \\
\hline
\end{tabular}

Note: Supported represents neither fully supported nor discarded. Source: Output from R.

Variables related to gender, type of operating digital store (apps or website), and the price of the product have very much less significance on internal consistency. The alpha value considerably decreases when they are removed. Customers have an almost balanced view of shifting to other stores and the image of the digital store, which makes the price have a substantial effect on the digital store image. If the price changes very much for similar products, then customers will shift to lesser-priced products. The availability of different products in the digital store also affects the pricing aspect. The education and empathetic nature of employees also affect the way customers complain, and the 
way delivery is handled, which is Factor 1 for the model. Factor 2 is promotion, pricing, billing ease, or proper billing, which influence the purchasing power of the customer. So, the service provider or digital store has to be cautious of certain socioeconomic variables.

Digital store image is significant when it comes to complaint handling methods, promotional aspects, and image-driven pricing. So the digital store has to be more careful about these factors. The education of customers and the period of which customer has been purchasing from the store also determine the significance of purchasing perception. Purchasing orientation also can be evaluated in terms of gender and occupation. But they are less significant than education and the period of purchase.

So, from the model, it can be concluded that digital consumers' socioeconomic profiles, the price of the product, the digital store's image appear to have a significant relationship. Consumers' profiles mean having the education and period of purchase which explain the relationship better. So the level of education and the period of purchase from a digital store have significant relationships with purchase intentions leading to loyalty. Thus, digital service providers should consider the level of knowledge and the period of continuous purchase from a digital store as the criteria for evaluating digital customer loyalty.

Digital store image appears to be substantial for grievances, promotions, and representation driven by price. So loyalty and profiles can be related by the expression "digital consumer loyalty $=\sim$ digital socioeconomic profile". So, this significant relationship has to be taken into consideration by the service provider while focusing on making decisions on loyalty.

\section{Conclusions, Recommendations, Limitations, and Future Research Implications}

\subsection{Conclusions}

Since, it is a simulation study for the nascent online store market in Vietnam, this research concludes in favour of the confirmatory factor analysis, which shows that there is a significant convergent relationship that exists among the variables. All variables signify a latent trait for the data. From the data, it can be concluded that gender and occupation best explain the suitability and ease of online digital store consumers. They prefer the quality of product and delivery along with payment suitability. This observation also holds true for the bi-factor exploratory analysis. The only difference between both the models is that the bi-factor model also explains that education has a considerable influence, along with gender. So albeit of these two models, gender remains the constant variable along with the price of the product, grievance handling mechanism, and promptness and security of payment. Since Vietnam is slowly increasing its economic development, it will be a great boost for online digital stores. Occupation and education have different responses due to the intervening effect of certain pertinent variables such as digital customer loyalty and a smooth billing process. Occupation-wise, sensitivity is present in terms of purchase orientation. Loyalty is pretty much a dominant force to reckon with, with price, quality of product, and favourability of purchase. This study also has evidence that customers are willing to switch if they find variety, price suitability, quick delivery, and overall peer group satisfaction for the products. So, it can be concluded that the online digital stores in Vietnam can be more prominent if they take care of customer loyalty, the pricing aspect, employee behavior, and comfort of customers in operation through mobile apps and websites. The findings of the study are not so different, but significantly show the trend of new age consumer preferences in a growing economy like Vietnam, which can be very helpful in giving significant input to the companies for forming strategies for new markets.

\subsection{Recommendations for Digital Stores Operating in Vietnam}

Digital stores can be more considerate of the arrangement of smooth payment and quick delivery so that the comfort of shopping and reliability on delivery can be ensured. That will propel digital customer loyalty to go up and make the right name image for the store. The brand value will increase with an overall increase in brand equity. 
Digital stores can anticipate higher profitability once they start to create a brand image in customers' minds related to quick delivery, courteous behavior, and, most importantly, they can vouch for the right image in the market.

Employee behavior, shopping comfort, social media promotion (e-WOM) will always enhance the image along with brand equity many times. So, stores should concentrate on their positive offerings to consumers.

In wake of recent developments in the tech-ecosystem of Vietnam, new innovative digital technologies will be integrated for online retail businesses such as the introduction of chatbots, AI, a 5G-enabled mobile service, and online service kiosks of different companies coming to Vietnam. So, in this context, this paper will certainly be helpful in giving them a definitive idea of how to go to interior markets and explore consumer psychology.

\subsection{Limitations, Future Research, and Practical Contributions for Social Impact}

Nevertheless, this study is limited to a certain region only. Digital customer loyalty and satisfaction for the digital socioeconomic profiles and digital store image are examined for prominent digital stores operating in Vietnam's Da Nang City. This study is based on perceptual and behavioral aspects. Future studies can, therefore, consider the negative factors which may affect the behavior of customers. Here $\mathrm{R}$ is used, so future studies can use more on this aspect to have a better model for study. Convenience sampling was used for this study and findings may not be generalized to the entire population. Future studies can use probability sampling. In future studies, both qualitative and quantitative methods can be used to gain deeper insights into various purchase orientations for online customers. A digital socioeconomic profile (DSP) denotes the online profile of the consumer from the demographic parameters. With the dynamism of the market, these attributes are subject to change in near future, such as preference for online payment, which may come into consideration. So, DSP is very valuable for online digital stores operating through apps or websites.

As the Vietnamese are slowly venturing into the online market in all departments, this study will provide a significant stimulative effect on market players. Consumers behavioral patterns can be revealed to them, which is very much helpful in their positioning strategy for the market. In recent months, Vietnamese premier online companies such as Grab and Be are rejigging their higher management in order to cope with the dynamism of the market scenario. Since these companies operate mostly through app-only platforms, consumer dissatisfaction directly hampers the image of the company. So, more online stores or companies oblige customer satisfaction by keeping profits at a rational margin until they have a good image because price sensitivity is very much found in the Vietnamese digital consumers' socioeconomic profiles.

Author Contributions: Conceptualization, S.S.; methodology, S.M.; software, S.D.; validation, L.B.S., K.K.S., and S.M.; formal analysis, S.D.; investigation, S.M.; resources, S.M.; data curation, S.D.; writing original draft-L.B.S., SM.; writing - review and editing, S.D.; visualization, S.D.; supervision, S.S. All authors have read and agree to the published version of the manuscript.

Funding: This research received no external funding.

Acknowledgments: We acknowledge all the customers who have given responses through the survey.

Conflicts of Interest: The authors declare no conflict of interest.

\section{References}

1. eCommerce. Available online: https://www.statista.com/outlook/243/127/ecommerce/vietnam (accessed on 23 February 2020).

2. Digital 2019 Spotlight: Ecommerce in Vietnam. Available online: https://datareportal.com/reports/digital2019-ecommerce-in-vietnam (accessed on 23 February 2020).

3. Euromonitor International. Grocery Retailers in Vietnam: Euromonitor International. 2014. Available online: https://www.euromonitor.com/traditional-grocery-retailers-in-vietnam/report (accessed on 23 February 2020). 
4. Tyng, G.; Truong, M.D. Vietnam: Retail Foods. Available online: https://www.fas.usda.gov/data/vietnamretail-foods-3 (accessed on 23 February 2020).

5. Nguyen, H.T.H.; Wood, S.; Wrigley, N. The emerging food retail structure of Vietnam. Int. J. Retail. Distrib. Manag. 2013, 41, 596-626. [CrossRef]

6. Phan, T.T.H.; Vu, P.A. The impact of marketing mix elements on food buying behavior: A study of supermarket consumers in Vietnam. Int. J. Bus. Manag. 2015, 10, 206.

7. Nguyen, T.N.; Lobo, A.; Nguyen, H.L.; Phan, T.T.H.; Cao, T.K. Determinants influencing conservation behaviour: Perceptions of Vietnamese consumers. J. Consum. Behav. 2016, 15, 560-570. [CrossRef]

8. Cao, T.K.; Dang, P.L.; Nguyen, H.A. Predicting consumer intention to use mobile payment services: Empirical evidence from Vietnam. Int. J. Mark. Stud. 2016, 8, 117-124.

9. Nguyen, H.V.; Nguyen, X.N.; Tran, V.T.; Nguyen, N. Evaluating the attributes of online bookstores: Empirical evidence from young consumers in Vietnam. Publ. Res. Q. 2019, 35, 236-241. [CrossRef]

10. Cao, T.K.; Phan, T.T.H. Cultural influences on overall service quality expectations: Evidence from Vietnamese customers. Asian Soc. Sci. 2015, 11, 151.

11. The Digital Consumer. The Deloitte Consumer Review: Digital Predictions 2018. Available online: https:/www2.deloitte.com/content/dam/Deloitte/uk/Documents/consumer-business/deloitte-ukconsumer-review-digital-predictions-2018.pdf (accessed on 23 February 2020).

12. Parasuraman, A.; Zeithaml, V.; Berry, L. SERVQUAL: A Multiple-Item Scale for measuring consumer perceptions of service quality. J. Retail. 1988, 64, 12-40, 140.

13. Dessart, L.; Veloutsou, C.; Morgan-Thomas, A. Consumer engagement in online brand communities: A social media perspective. J. Prod. Brand. Manag. 2015, 24, 28-42. [CrossRef]

14. Consumer Views and Behaviours on Digital Platforms. Australian Competition and Consumer Commission. Available online: https://www.accc.gov.au/system/files/ACCC \%20consumer\%20survey\%20-\%20Consumer\% 20views\%20and\%20behaviours\%20on\%20digital\%20platforms\%2C\%20Roy\%20Morgan\%20Research.pdf (accessed on 23 February 2020).

15. Ashley, C.; Tuten, T. Creative Strategies in Social Media Marketing: An Exploratory Study of Branded Social Content and Consumer Engagement. Psychol. Mark. 2014, 32, 15-27. [CrossRef]

16. Clottey, T.; Collier, D.; Stodnick, M. Drivers of Customer Loyalty in A Retail Store Environment. J. Serv. Sci. 2008, 1, 35-48. [CrossRef]

17. Singh, I.; Nayyar, A.; Le, D.H.; Das, S. A conceptual analysis of internet banking users' perceptions. An Indian perceptive. Rev. Espac. 2019, 40,1.

18. Das, S.; Nayyar, A.; Singh, I. An assessment of forerunners for customer loyalty in the selected financial sector by SEM approach toward their effect on business. Date Technol. Appl. 2019, 53, 546-561. [CrossRef]

19. Subhankar, D.; Anand, N. Digital sustainability in social media innovation: A microscopic analysis of Instagram advertising \& its demographic reflection for buying activity with R. In Proceedings of the 1st International Scientific Conference, Ekaterinburg, Russia, 14-15 April 2019; Atlantis Press: Paris, France.

20. Yan, Q.; Zhou, S.; Zhang, X.; Li, Y. A System Dynamics Model of Online Stores' Sales: Positive and Negative E-WOM and Promotion Perspective. Sustainability 2019, 11, 6045. [CrossRef]

21. Gupta, D.K.; Jena, D.; Samantaray, A.K.; Das, S. HRD climate in selected public sector banks in India. Rev. Espac. 2019, 40, 14.

22. Diallo, M. Effects of store image and store brand price-image on store brand purchase intention: Application to an emerging market. J. Retail. Consum. Serv. 2012, 19, 360-367. [CrossRef]

23. Sharma, R. Understanding the Role of Store Image in Influencing Customer-based Brand Equity and Its Dimensions in Indian Sportswear Industry. Manag. Labour Stud. 2017, 42, 167-189. [CrossRef]

24. Smith, R.; Sherman, E. Effects of Store Image and Mood on Consumer Behavior: A Theoretical and Empirical Analysis. ACR N. Am. Adv. 1993, 20,631.

25. Zhang, J.; Luximon, Y.; Song, Y. The Role of Consumers' Perceived Security, Perceived Control, Interface Design Features, and Conscientiousness in Continuous Use of Mobile Payment Services. Sustainability 2019, 11, 6843. [CrossRef]

26. Mondal, S.; Das, S.; Musunuru, K.; Dash, M. Study on the factors affecting customer purchase activity in retail stores by confirmatory factor analysis. Rev. Espac. 2017, 38, 30-55.

27. Kumar Sahoo, K.; Mondal, S. An Analysis of Impact of Electronic Customer Relationship Management (e-CRM) on Service Quality of E-Retail Stores: A Study of Bhubaneswar. Res. Revolut. 2016, 2, 10-12. 
28. Chicu, D.; del Mar Pàmies, M.; Ryan, G.; Cross, C. Exploring the influence of the human factor on customer satisfaction in call centers. Brq Bus. Res. Q. 2019, 22, 83-95. [CrossRef]

29. Mathwick, C.; Malhotra, N.; Rigdon, E. Experiential value: Conceptualization, measurement, and application in the catalog and Internet shopping environment. J. Retail. 2001, 77, 39-56. [CrossRef]

30. Yoo, B.; Donthu, N. Developing a scale to measure the perceived quality of an Internet shopping site (SITEQUAL). Q. J. Electron. Commer. 2001, 2, 31-45.

31. Wolfinbarger, M.; Gilly, M.C. eTailQ: Dimensionalizing, measuring, and predicting etail quality. J. Retail. 2003, 79, 183-198. [CrossRef]

32. Jin, B.; Park, J.Y. The moderating effect of online purchase experience on the evaluation of online store attributes and the subsequent impact on market response outcomes. ACR N. Am. Adv. 2006, 33, 203-211.

33. Retail in Vietnam: Navigating the Digital Retail Landscape. Available online: https://www2.deloitte.com/ content/dam/Deloitte/vn/Documents/consumer-business/vn-cb-vietnam-consumer-retail-2019.pdf (accessed on 23 February 2020).

34. Das, S.; Mondal, S.R.; Sahoo, K.K.; Nayyar, A.; Musunuru, K. Study on the Impact of socioeconomic makeup of Facebook users on purchasing behavior. Rev. Espac. 2018, 39, 28-42.

35. Meseguer-Artola, A.; Rodríguez-Ardura, I. Learning from customer interaction: How merchants create price-level propositions for experience goods in hybrid market environments. Comput. Hum. Behav. 2015, 51, 952-959. [CrossRef]

36. Mondal, S.; Mall, M.; Mishra, U.S.; Sahoo, K. Investigating the factors affecting customer purchase activity in retail stores. Rev. Espac. 2017, 38, 22.

37. Manikanandan. Drivers of Customer Loyalty in a Retail Store Environment. J. Serv. Sci. 2012, 1, 35-47.

38. Chen-Yu, J.; Hong, K.H. Antecedents and consequences of consumer satisfaction/dissatisfaction with the performance of apparel products at purchase and after consumption: A comparison of male and female South Korean consumers. Int. J. Consum. Stud. 2002, 26, 117-127. [CrossRef]

39. Chang, C.H.; Tu, C.Y. Exploring store image, customer satisfaction, and customer loyalty relationship: Evidence from Taiwanese hypermarket industry. J. Am. Acad. Bus. 2005, 7, 197-202.

40. Ali, F.; Zhou, Y.; Hussain, K.; Nair, P.K.; Ragavan, N.A. Does higher education service quality effect student satisfaction, image, and loyalty? A study of international students in Malaysian public universities. Qual. Assur. Educ. 2016, 24, 70-94. [CrossRef]

41. Ali, F.; Ryu, K.; Hussain, K. Influence of experiences on memories, satisfaction, and behavioral intentions: A study of creative tourism. J. Travel Tour. Mark. 2016, 33, 85-100. [CrossRef]

42. Ali, F.; Amin, M. The influence of physical environment on emotions, customer satisfaction, and behavioral intentions in Chinese resort hotel industry. J. Glob. Bus. Adv. 2014, 7, 249-266. [CrossRef]

43. Grace, D. Consumer disposition toward satisfaction (CDS): Scale development and validation. J. Mark. Theory Pract. 2005, 13, 20-31. [CrossRef]

44. Ali, F. Hotel website quality, perceived flow, customer satisfaction, and purchase intention. J. Hosp. Tour. Technol. 2016, 7, 213-228. [CrossRef]

45. Singh, H.; Prashar, S. Anatomy of shopping experience for malls in Mumbai: A confirmatory factor analysis approach. J. Retail. Consum. Serv. 2014, 21, 220-228. [CrossRef]

46. Chebat, J.C.; Haj-Salem, N.; Oliveira, S. Why shopping pals make malls different? J. Retail. Consum. Serv. 2014, 21, 77-85. [CrossRef]

47. Paul, J.; Sankaranarayanan, K.G.; Mekoth, N. Consumer satisfaction in retail stores: Theory and implications. Int. J. Consum. Stud. 2016, 40, 635-642. [CrossRef]

48. Zeithaml, V.A.; Berry, L.L.; Parasuraman, A. The nature and determinants of customer expectations of service. J. Acad. Mark. Sci. 1993, 21, 1-12. [CrossRef]

49. Zeithaml, V.A.; Parasuraman, A.; Berry, L.L. Delivering Quality Service: Balancing Customer Perceptions and Expectations; Simon and Schuster: New York, NY, USA, 1990.

50. Zeithaml, V.A. Service quality, profitability, and the economic worth of customers: What we know and what we need to learn. J. Acad. Mark. Sci. 2000, 28, 67-85. [CrossRef]

51. Parasuraman, A.; Berry, L.L.; Zeithaml, V.A. More on improving service quality measurement. J. Retail. 1993, 69, 140-147. [CrossRef]

52. Parasuraman, A.; Zeithaml, V.A.; Berry, L.L. Alternative scales for measuring service quality: A comparative assessment based on psychometric and diagnostic criteria. J. Retail. 1994, 70, 201-230. [CrossRef] 
53. Dabholkar, P.A.; Thorpe, D.I.; Rentz, J.O. A measure of service quality for retail stores: Scale development and validation. J. Acad. Mark. Sci. 1996, 24, 3-16. [CrossRef]

54. Tsikriktsis, N. Does Culture Influence Web Site Quality Expectations? An Empirical Study. J. Serv. Res. 2002, 5, 101-112. [CrossRef]

55. Brady, M.K.; Cronin, J.J.; Brand, R.R. Performance-only measurement of service quality: A replication and extension. J. Bus. Res. 2002, 55, 17-31. [CrossRef]

56. Cronin, J.J.; Brady, M.K.; Hult, G.T.M. Assessing the effects of quality, value, and customer satisfaction on consumer behavioral intentions in service environments. J. Retail. 2000, 76, 193-218. [CrossRef]

57. Baker, J.; Grewal, D.; Parasuraman, A. The influence of store environment on quality inferences and store image. J. Acad. Mark. Sci. 1994, 22, 328-339. [CrossRef]

58. Bolton, R.N.; Drew, J.H. A longitudinal analysis of the impact of service changes on customer attitudes. J. Mark. Res. 1991, 55, 1. [CrossRef]

59. Brady, M.K.; Cronin, J.J. Some new thoughts on conceptualizing perceived service quality: A hierarchical approach. J. Mark. Res. 2001, 65, 34-49. [CrossRef]

60. Powpaka, S. The role of outcome quality as a determinant of overall service quality in different categories of services industries: An empirical investigation. J. Serv. Mark. 1996, 10, 5-25. [CrossRef]

61. Reimer, A.; Folkes, V. Consumers' inferences about quality across diverse service providers. Psychol. Mark. 2009, 26, 1066-1078. [CrossRef]

62. French, S.A. Pricing effects on food choices. J. Nutr. 2003, 133, 841S-843S. [CrossRef] [PubMed]

63. Nevin, S.; Suzan Seren, K. Evaluation of food purchasing behaviour of consumers from supermarkets. Br. Food J. 2010, 112, 140-150. [CrossRef]

64. Barbara, O.; Lois, S.; Bobby, V. A psychographic study of the elderly and retail store attributes. J. Consum. Mark. 1996, 13, 14-27. [CrossRef]

65. Pan, Y.; Zinkhan, G.M. Determinants of retail patronage: A meta-analytical perspective. J. Retail. 2006, 82, 229-243. [CrossRef]

66. Dodds, W.B.; Monroe, K.B.; Grewal, D. Effects of Price, Brand, and Store Information on Buyers' Product Evaluations. J. Mark. Res. 1991, 28, 307-319. [CrossRef]

67. Kerin, R.A.; Jain, A.; Howard, D.J. Store Shopping Experience and Consumer Price-Quality-Value Perceptions. J. Retail. 1992, 68, 376.

68. Figuié, M.; Moustier, P. Market appeal in an emerging economy: Supermarkets and poor consumers in Vietnam. Food Policy 2009, 34, 210-217. [CrossRef]

69. French, S.A.; Story, M.; Jeffery, R.W.; Snyder, P.; Eisenberg, M.; Sidebottom, A.; Murray, D. Pricing strategy to promote fruit and vegetable purchase in high school cafeterias. J. Am. Diet. Assoc. 1997, 97, 1008-1010. [CrossRef]

70. Hansen, T. Intertype competition: Secialty food stores competing with supermarkets. J. Retail. Consum. Serv. 2003, 10, 35-49. [CrossRef]

71. Dunne, P.; Lusch, R.; Carver, J. Retailing, 7th ed.; Cengage Learning: Boston, MA, USA, 2010.

72. Turley, L.W.; Chebat, J.C. Linking Retail Strategy, Atmospheric Design and Shopping Behaviour. J. Mark. Manag. 2002, 18, 125-144. [CrossRef]

73. Hu, H.; Jasper, C.R. Social cues in the store environment and their impact on store image. Int. J. Retail. Distrib. Manag. 2006, 34, 25-48. [CrossRef]

74. Maruyama, M.; Trung, L.V. Supermarkets in Vietnam: Opportunities and Obstacles. Asian Econ. J. 2007, 21, 19-46. [CrossRef]

75. Das, S.; Dash, M.; Sahoo, K.; Mishra, U.S. Study on effectiveness of celebrity endorsements in print \& social media advertisements on the buying behavior of consumers. Rev. Espac. 2018, 39, 28.

76. Dick, A.S.; Basu, K. Customer loyalty: Toward an integrated conceptual framework. J. Acad. Mark. Sci. 1994, 22, 99-113. [CrossRef]

77. Orel, F.D.; Kara, A. Supermarket self-checkout service quality, customer satisfaction, and loyalty: Empirical evidence from an emerging market. J. Retail. Consum. Serv. 2014, 21, 118-129. [CrossRef]

78. Das, G. Impacts of retail brand personality and self-congruity on store loyalty: The moderating role of gender. J. Retail. Consum. Serv. 2014, 21, 130-138. [CrossRef]

79. Rezaei, S.; Ali, F.; Amin, M.; Jayashree, S. Online impulse buying of tourism products: The role of web site personality, utilitarian, and hedonic web browsing. J. Hosp. Tour. Technol. 2016, 7, 60-83. [CrossRef] 
80. Beristain, J.J.; Zorrilla, P. The relationship between store image and store brand equity: A conceptual framework and evidence from hypermarkets. J. Retail. Consum. Serv. 2011, 18, 562-574. [CrossRef]

81. Pham, T.H.; Nguyen, T.N.; Phan, T.T.H.; Nguyen, N.T. Evaluating the purchase behaviour of organic food by young consumers in an emerging market economy. J. Strat. Mark. 2019, 27, 540-556. [CrossRef]

82. Nguyen, H.T.; Nguyen, H.; Nguyen, N.D.; Phan, A.C. Determinants of customer satisfaction and loyalty in Vietnamese life-insurance setting. Sustainability 2018, 10, 1151. [CrossRef]

83. Saunders, M.; Lewis, P.; Thornhill, A. Research Methods for Business Students; Pearson Education: Chennai, India, 2012.

84. Orçan, F. Exploratory and confirmatory factor analysis: Which one to use first? J. Meas. Eval. Educ. Psychol. 2018, 9, 414-421. [CrossRef]

85. Orcan, F.; Yanyun, Y.A.N.G. A note on the use of item parceling in structural equation modeling with missing data. Eğitimde Ve Psikol. Ölçme Ve Değerlendirme Derg. 2016, 7, 59-72.

86. Green, S.B.; Salkind, N.J.; Jones, T.M. Using SPSS for Windows; Analyzing and Understanding Data; Prentice Hall PTR: Upper Saddle River, NJ, USA, 1996.

87. Podsakoff, P.M.; MacKenzie, S.B.; Lee, J.Y.; Podsakoff, N.P. Common method biases in behavioral research: A critical review of the literature and recommended remedies. J. Appl. Psychol. 2003, 88, 879. [CrossRef] [PubMed]

88. Podsakoff, P.M.; MacKenzie, S.B.; Podsakoff, N.P. Sources of method bias in social science research and recommendations on how to control it. Annu. Rev. Psychol. 2012, 63, 539-569. [CrossRef]

89. Hair, J.F.; Black, W.C.; Babin, B.J.; Anderson, R.E.; Tatham, R.L. Multivariate Data Analysis; Prentice Hall: Upper Saddle River, NJ, USA, 1998; Volume 5.

90. Hair, J.F.; Black, W.C.; Babin, B.J.; Anderson, R.E. Multivariate Data Analysis, 7th ed.; Prentice Hall: Upper Saddle River, NJ, USA, 2010.

(C) 2020 by the authors. Licensee MDPI, Basel, Switzerland. This article is an open access article distributed under the terms and conditions of the Creative Commons Attribution (CC BY) license (http://creativecommons.org/licenses/by/4.0/). 